\title{
Influências da incapacidade civil e do discernimento reduzido em matéria de prescrição e decadência
}

\author{
Influences of civil incapacity and impaired discernment on prescription and \\ peremption
}

\author{
Eduardo Nunes de Souza* \\ Rodrigo da Guia Silva**
}

\section{Resumo}

\begin{abstract}
O presente artigo procura investigar de que modo o discernimento do titular do direito ou do dever jurídico influencia o regime jurídico da prescrição e da decadência. Para tanto, analisa-se o regime jurídico do termo inicial da prescrição e da decadência no direito brasileiro, à luz particularmente do princípio contra non valentem agere non currit praescriptio. A investigação propõe soluções inovadoras para problemas relacionados à prescrição em face do relativamente incapaz e das pessoas com deficiência psíquica ou intelectual após a reforma promovida pelo Estatuto da Pessoa com Deficiência.
\end{abstract}

Palavras-chave: Incapacidade. Discernimento. Prescrição. Decadência. Pessoa com deficiência.

\section{Abstract}

This article seeks to investigate in which ways the discernment of the right owner or of the debtor influences the legal discipline of prescription and peremption. For that purpose, it analyses the legal discipline of the initial term of prescription and peremption in Brazilian law, particularly in the light of the principle contra non valentem agere non currit praescriptio. This investigation proposes innovative solutions to problems related to prescription against the relatively incapable as well as people with psychic or intellectual disabilities after the reform made by the Inclusion of People with Disabilities Act.

Keywords: Incapacity. Discernment. Prescription. Peremption. Person with disability.

\section{Introdução}

Gerações de juristas têm sido apresentadas ao tradicional instituto da prescrição por intermédio do adágio latino vigilantibus, non dormientibus, sucurrit ius. Segundo entendimento clássico, a máxima traduz um dos mais antigos fundamentos atribuídos à sujeição das pretensões jurídicas ao decurso do tempo: o papel de punir o titular que se mantém inerte em seu exercício (DANTAS, 2001, p. 342). Tão antigo é o fundamento, aliás, que a doutrina contemporânea já tem posto em dúvida sua adequação. Seria, de fato, a inércia do titular a razão de ser da prescrição? Em caso afirmativo, essa inércia seria sempre

Doutor e mestre em Direito Civil pela Universidade do Estado do Rio de Janeiro (UERJ). Professor Adjunto de Direito Civil da Faculdade de Direito da UERJ. Rio de Janeiro - RJ - Brasil. E-mail: eduardo.souza@uerj.br.

Mestrando em Direito Civil pela Universidade do Estado do Rio de Janeiro (UERJ). Membro do Instituto Brasileiro de Direito Civil (IBDCivil) e do Comitê Brasileiro da Association Henri Capitant des Amis de la Culture Juridique Française (AHC-Brasil). Advogado. Rio de Janeiro - RJ - Brasil. E-mail: rodrigo.daguiasilva@gmail.com. 
punível? Eminentes vozes já se insurgiram, no direito brasileiro e alhures, contra essa concepção. ${ }^{1}$ Afirmase, por exemplo, que, se fosse esse o real fundamento da prescrição, o reconhecimento do crédito pelo devedor não poderia jamais atuar como causa obstativa do prazo prescricional. ${ }^{2}$ Além disso, segundo alguns autores, a regra de que a prescrição apenas se interrompe uma vez seria incompatível com esse tradicional ponto de vista (GUEDES; LGOW, 2014, p. 1846).

A associação da prescrição a uma suposta punição do credor inerte tem mais de uma explicação possível. A primeira e mais evidente consiste no fato de o decurso do tempo parecer prejudicar o titular do direito e beneficiar a parte contraposta na relação jurídica. ${ }^{3} \mathrm{~A}$ segunda, não menos relevante, é de ordem sistemática: como se sabe, a questão central com que lida o direito civil reside no controle valorativo da autonomia privada. De fato, estando os atos da vida civil sujeitos a um regime que presume a liberdade de agir, mas a submete ao crivo axiológico do ordenamento (como informa o princípio da legalidade em sua vertente privatista), ${ }^{4}$ coloca-se para o jurista o problema de saber quando e de que modo certas condutas particulares receberão um tratamento repressivo, desfavorável ao agente. Assim tem sido ao longo de séculos, e mesmo o atual ambiente, de acentuada funcionalização da autonomia privada à solidariedade constitucional, não parece alterar essa preocupação central. ${ }^{5}$ Resulta, assim, natural que também a prescrição aparente decorrer da valoração negativa de um comportamento particular (a inércia do titular de um direito) e da necessidade de sancioná-lo.

No entanto, um aspecto (este sim) drasticamente modificado com a progressiva constitucionalização do direito civil foi a própria noção de legalidade, cada vez mais voltada à ideia de merecimento de tutela. ${ }^{6}$ Em um cenário de pluralidade de fontes normativas e crescente complexificação social, constata-se a insuficiência da função repressiva do direito para a solução de conflitos particulares (BOBBIO, 2007, p. 15). Nos casos, não mais tão raros, em que dois comportamentos privados, em princípio amparados pelo direito, entram em rota de colisão, impõe-se ao intérprete ponderar qual deles atende de modo mais satisfatório a uma função promocional para conferir-lhe tutela prioritária (SOUZA, 2014, item 5). Esse juízo meritório se observa em todas as searas do direito civil: procura-se cada vez menos pelo culpado e cada vez mais pelo vulnerável; cada vez menos pela repressão e cada vez mais pela prevenção; cada vez menos pela extinção dos atos desconformes e cada vez mais pelo equilíbrio dos interesses. E o mesmo processo parece ter chegado ao campo da prescrição: a punição do titular do direito tornou-se a última das preocupações do intérprete, que passa a atentar, prioritariamente, para a ponderação entre os interesses contrapostos, buscando identificar qual deles merecerá a tutela prioritária do sistema. ${ }^{7}$

O enquadramento da prescrição como um problema de merecimento de tutela, em sentido estrito, parece responder a um antigo desconforto da doutrina, que entrevia no instituto um reflexo do perene embate entre justiça e segurança jurídica. ${ }^{8} \mathrm{Se}$, de fato, na generalidade dos casos, o sentido de justiça

Na doutrina italiana, aduz Pier Giuseppe Monateri: "A teoria da inércia pressuporia um alcance moralístico que parece estranho ao tratamento científico da matéria, mesmo porque, se coerentemente assumida, ela reconduziria os efeitos da prescrição, de fato, entre as sanções civis. Diversamente, tanto o campo da prescrição, quanto por outro lado aquele da decadência ou da nulidade em linguagem sancionatória ('sob pena de decadência', 'sob pena de nulidade'), refletem agora posições em desuso, e só podem ser entendidos como metáfora de efeitos que não são mais cientificamente considerados como sanções” (MONATERI, 2009, p. 28. Tradução livre). No direito brasileiro, registra Caio Mário da Silva Pereira (2016, p. 572): "nosso direito pré-codificado via [na prescrição] uma punição ao credor negligente, o que não é de boa juridicidade, pois que punível deve ser o comportamento contraveniente à ordem constituída, e nada comete contra ela aquele que mais não fez do que cruzar os braços contra os seus próprios interesses".

Com esse argumento, por exemplo, Pier Giuseppe Monateri (2009, p. 24) afasta a tese de uma suposta renúncia tácita pelo titular do direito como fundamento da prescrição.

3 "No campo do Direito privado, o interesse do credor será, sempre, o de dispor de um máximo de pretensões, podendo ordenar no tempo, de acordo com conveniências suas, o exercício dos seus direitos. Temos, pois, de assumir que a prescrição visa, no essencial, tutelar o interesse do devedor: uma orientação que se comprova, em termos históricos, desde Teodósio II" (CORDEIRO, 2015, p. 197).

Sobre a evolução do princípio da legalidade em direção ao controle da abusividade e do merecimento de tutela, cf. SOUZA, 2014, passim. Sobre a referida funcionalização da autonomia privada ao princípio da solidariedade social, cf. a lição de PERLINGIERI, 2008 , p. $341-342$.

Sobre o sentido estrito de merecimento de tutela ora adotado como instância de controle positivo dos atos de autonomia privada, embasada na função promocional do direito e na ponderação de interesses que não possam conviver em concreto, cf. SOUZA, 2014, itens 3-5.

Nesse sentido, aduz-se que "os próprios objetivos de tutela das normas sobre a prescrição estão hoje se movendo progressivamente do interesse público e abstrato da certeza das relações à ponderação funcional dos interesses das partes” (LONGOBUCCO, 2012, p. 952. Tradução livre).

8 A respeito, leciona San Tiago Dantas (2001, p. 342): "Como se explica esta restrição em que as próprias sanções jurídicas introduzem a instabilidade dos direitos subjetivos? [...] Esta influência do tempo consumido pelo direito pela inércia do titular serve a uma das finalidades supremas da ordem jurídica que é estabelecer a segurança das relações sociais". 
parece favorecer o titular do direito e a noção de segurança jurídica parece amparar a contraparte, seria ao menos ingênuo considerar, no cenário atual, que o problema se resolve em termos absolutos, a favor ou contra um desses polos. Contudo, a substituição do tratamento punitivista da prescrição por uma perspectiva de merecimento de tutela acarreta também novas dificuldades ao intérprete. Nesse sentido, se não se trata mais de punir a inércia, seria possível concluir que deixou de ser necessário qualquer critério subjetivo para que se imponha a alguém a consequência negativa de ver extinta sua pretensão? ${ }^{9} \mathrm{~A}$ lógica da prescrição, quanto a esse aspecto, objetivou-se; e, aos olhos do intérprete menos habituado à análise funcional dos institutos, certas regras ligadas a atributos subjetivos do titular poderiam perder sentido - por exemplo, a regra de que sua capacidade civil condiciona a fluência da prescrição.

Com efeito, se a inércia do titular do direito não é uma conduta a ser censurada, poderia, de início, parecer estranha à técnica da prescrição a atribuição de qualquer relevância à capacidade desse titular. Tal impressão preliminar ganha fôlego no cenário atual, após a reforma promovida pela Lei n. 13.146/2015 (o Estatuto da Pessoa com Deficiência), que, alterando drasticamente a teoria geral do direito civil, conferiu capacidade civil plena a todas as pessoas com deficiência intelectual ou psíquica (até então reputadas incapazes, absoluta ou relativamente, de acordo com seu grau de discernimento). ${ }^{10}$ Se a superação da visão punitivista já punha em dúvida a proteção dos absolutamente incapazes contra a fluência da prescrição, a reforma parece ter criado um quadro ainda mais desigual, tornando quase impossível oferecer a mesma proteção às pessoas com deficiência mental (que, no regime anterior, estavam abrigadas pelo regime protetivo da incapacidade civil). Surge, assim, uma nova dúvida: o maior de idade ou emancipado sujeitase à prescrição ainda que seja desprovido de discernimento?

Uma resposta preliminar poderia ser extraída do art. 121, parágrafo único, do Estatuto da Pessoa com Deficiência, que dispõe: "prevalecerá a norma mais benéfica à pessoa com deficiência". A regra talvez bastasse para obstar a prescrição contra essas pessoas; não é, porém, o que ocorre, e por diversas razões. A primeira, de ordem metodológica, consiste no problema de se defenderem interpretações "a todo custo" em prol da pessoa com deficiência, transformando-se essa categoria em um super-status, um espaço de proteção desmesurada e, portanto, assistemática. Desse mal já padece, por exemplo, o direito do consumidor, como critica autorizada doutrina. ${ }^{11}$ Além disso, não se sabe sequer se a prescrição é um fenômeno contra o qual essas pessoas devam ser protegidas. Como mencionado, no direito atual, ainda se busca um motivo que explique se até mesmo outros vulneráveis, como os menores impúberes, precisam desse tipo de proteção. Mais ainda, não há certeza nem mesmo quanto ao nível de proteção que a Lei n. 13.146/2015 pretendeu conferir às pessoas com deficiência mental, já que as desprotegeu quando retirou delas o estatuto da incapacidade civil. ${ }^{12}$

Não se trata, por certo, de desproteção arbitrária. A lei buscou libertar essas pessoas do estigma social, da marginalização - e, como se sabe, toda liberdade nasce geminada com a responsabilidade e com a autorresponsabilidade: ${ }^{13}$ quem age livremente deve poder discernir as consequências que acarreta

9 Assim afirma, por exemplo, na doutrina italiana, Pier Giuseppe Monateri: “[...] é opinião unânime que a inércia deva ser valorada objetivamente, a prescindir dos motivos e das intenções de quem não exerce o próprio direito. [...] Em substância, no nosso ordenamento, a inércia do titular se reduz à falta do exercício do direito, sem qualquer outra consideração dos seus motivos ou do seu comportamento ainda que objetivamente considerado" (MONATERI, 2009, p. 22-23. Tradução livre).

10 Como se observou em outra sede, uma presunção absoluta de capacidade da pessoa com deficiência mental ignoraria o seu concreto discernimento e a sua real vulnerabilidade (SOUZA; SILVA, 2016, p. 25).

11 A respeito, Gustavo Tepedino critica o pensamento microssistemático como "grave fragmentação do sistema, permitindo a convivência de guetos legislativos isolados" (TEPEDINO, 2011, p. 69).

12 Como se teve oportunidade de observar em outra sede, o novo regime, na contramão do propósito nobre que permeia a Lei n. $13.146 / 2015$ parece proporcionar, em alguns pontos, proteção menos intensa às pessoas com deficiência mental do que o regime anterior, pois retirou do texto codificado a referência ao discernimento, critério aclamado pela doutrina especializada como essencial à sua proteção (SOUZA; SILVA, 2016, p. 25).

13 A diferença é explicitada por Mauro Tescaro: "na responsabilidade se encontra [...] a violação de deveres jurídicos, com a consequente lesão de interesses alheios, o que não parece, ao revés, ocorrer nas hipóteses de autorresponsabilidade, nas quais um sujeito tem um comportamento lesivo, ao menos em via direta, e ressalvada a subsistência de efeitos indiretos sobre os interesses de terceiros, dos próprios interesses e, justamente por esse motivo, suporta integralmente suas consequências negativas, que parecem terminar a seu encargo [...] quase de modo automático ou naturalístico" (TESCARO, 2006, p. 119-120. Tradução livre). Sobre esse ponto, leciona Salvatore Pugliatti que a autorresponsabilidade reside justamente na imposição das consequências de uma ação ou omissão a um agente, isto é, ao seu patrimônio ou, de modo mais geral, sua esfera jurídica (PUGLIATTI, 2011, p. 205). 
para terceiros e para si mesmo, e por elas responder. ${ }^{14}$ Foi essa desproteção, reflexo da aspiração por liberdade, que o Estatuto outorgou às pessoas com deficiência mental. Se a emancipação foi o caminho certo para a promoção dos propósitos da lei, dadas as escolhas radicais do trabalho legislativo, trata-se de questão ora confiada à doutrina, que deverá aferir os sucessos e os excessos da reforma. É essa a tarefa a que se lança o presente estudo, particularmente em matéria de prescrição. Ao longo da exposição, o exemplo da pessoa com deficiência mental servirá também à análise de outros problemas há muito existentes nessa seara. $\mathrm{O}$ advento do Estatuto da Pessoa com Deficiência teve, aliás, dentre tantos outros méritos, este inegável papel: o de motivar o intérprete a voltar novamente os olhos para a teoria geral do direito civil, tão cheia de incertezas sob a aparente segurança de seus institutos multisseculares, e tantas vezes posta à prova pela evolução da sociedade e do direito.

\section{Perfil funcional da incapacidade civil e sua relação com a deflagração dos prazos prescricionais e decadenciais}

$\mathrm{Na}$ esteira de outros países da família romano-germânica, seguidos também pelo Código Civil de 1916, dispõe o art. 198, I, do Código Civil de 2002 que não corre a prescrição "contra os incapazes de

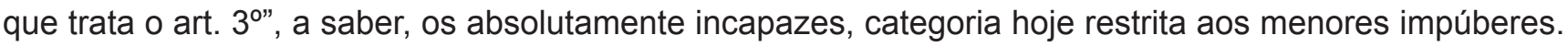
A regra é bastante direta e, em uma interpretação puramente estrutural, não suscitaria maiores dúvidas. Em perspectiva civil-constitucional, porém, partindo-se da premissa de que a suposta clareza de uma norma apenas decorre do próprio processo hermenêutico (PERLINGIERI, 2008, p. 616), cumpre indagar qual fundamento valorativo tem levado tantas codificações e, em particular, a brasileira, a disporem nesse sentido. Quando abordada por esse viés, a aparente clareza da norma se esvai, e deixa ao intérprete uma frustrante escassez de respostas dogmáticas.

Com enorme frequência, a previsão do art. 198, I, do Código Civil é explicada pela civilística em tom de naturalidade: os incapazes demandariam evidente tratamento diferenciado, e a regra nada mais fez que Ihes conferir uma "proteção", ${ }^{15}$ uma "isenção favorável", ${ }^{16}$ um "favor", ${ }^{17}$ uma "garantia", ${ }^{18}$ em atenção a "razões defensivas". ${ }^{19} \mathrm{~A}$ indagação que imediatamente decorre de tais afirmativas haveria, então, de ser: de qual ameaça específica os incapazes devem ser protegidos? Ordinariamente, o direito tutela pessoas vulneráveis contra atos de autonomia privada, isto é, atos realizados por (ou em conjunto com) outras pessoas que com elas interagem (pense-se nos casos nos quais se nega eficácia a negócios abusivos ou leoninos), e não contra efeitos criados pela própria norma jurídica. Poder-se-ia dizer, nessa direção, que os incapazes devem ser protegidos, na verdade, contra um fato jurídico: o próprio decurso do tempo, um fato natural. ${ }^{20}$ Contudo, o tempo, em si considerado, não aparenta oferecer uma ameaça propriamente

14 Como pondera Maria Celina Bodin de Moraes: "O discernimento, ou a capacidade de compreensão e análise, provém de uma característica da condição humana, se não a mais importante, a que melhor define a nossa espécie: a racionalidade. [...] O exercício da liberdade - e com ela a responsabilidade - está condicionado, no âmbito do direito, à capacidade, a qual por sua vez se funda no discernimento, na racionalidade do sujeito" (BODIN DE MORAES, 2010, p. 192-193). Para uma análise do papel do discernimento à luz do pensamento dworkiniano, cf. MENEZES, 2015, p. 14-15.

15 Parece predominar na doutrina a noção de que o art. 198, I, do Código Civil "confirma, mais uma vez, a preocupação que o legislador teve em

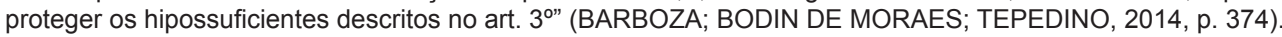

16 Para Câmara Leal (1959, p. 162), "o Código criou uma isenção favorável aos incapazes, que somente os beneficia, não permitindo contra eles a prescrição, de modo que corre a favor deles a prescrição das ações contra eles intentáveis” .

17 Afirma Luiz Carpenter (1958, p. 330) que a lei "visa favorecer as pessoas a que se refere. Por isso, suspende o curso da prescrição das ações que elas tiverem contra alguém, [...]"

18 Aduz Ferreira Coelho que a lei demonstra o cuidado em que devem ser tidos os absolutamente incapazes para dirigir sua pessoa e seus bens: "a todas as mais garantias pessoais e reais, ainda acresce esta de não correr contra estas pessoas o tempo para a prescrição" (COELHO, 1933, p. 68).

19 Segundo Caio Mário da Silva Pereira (2016, p. 583), "razões defensivas ou de proteção impedem ou suspendem a prescrição contra os absolutamente incapazes [...]".

20 Ao sustentar que a prescrição não apresenta nenhum aspecto volitivo ou negocial, Pier Giuseppe Monateri ressalta a relevância de se reconsiderar o tempo "como o mais importante dentre os fatos naturais [...]. Essa duração concreta é um fato e não pode não ser um elemento da hipótese fática [...]" (MONATERI, 2009, p. 25. Tradução livre). A noção, porém, não é pacífica. Outros autores afirmam que "a doutrina está hoje concorde em excluir o mero decurso do tempo do grupo dos verdadeiros e próprios fatos jurídicos: tempus non est modus constituendi vel dissolvendi iuris" (TESCARO, 2006, p. 4. Tradução livre). 
dita ao incapaz - é a eficácia preclusiva atribuída ao decurso do tempo pela ordem jurídica ${ }^{21}$ que parece prejudicá-lo. Retorna-se, assim, à questão anterior: A norma jurídica busca proteger o incapaz contra seus próprios efeitos?

Abordagem diversa é proposta por certa corrente doutrinária que, ainda sob a égide da codificação anterior, afirmava que a incapacidade civil criaria uma situação de "inferioridade na vida civil", motivo pelo qual seria justificável, em contrapartida, salvaguardar os interesses do incapaz por meio de um "favor especial". ${ }^{22}$ Embora nem sempre enunciada expressamente, tal concepção parece permear a mentalidade dos juristas há diversas gerações: $A$ isenção da prescrição funcionaria como uma espécie de "compensação" pela capitis deminutio, ${ }^{23}$ uma satisfação do ordenamento à suposta "inferiorização" decorrente do status de incapaz. A noção de que a categoria da incapacidade civil seria eminentemente discriminatória, aliás, parece ter sido um fator determinante para a reforma do instituto. Há mesmo autores que afirmam textualmente que as pessoas com deficiência mental sofriam preconceito e segregação social em decorrência do termo "incapaz", que designava seu estado pessoal no âmbito jurídico. ${ }^{24}$

No entanto, tal concepção peca por atribuir ao regime original da incapacidade civil funções que jamais foram concebidas para ele. Analisado objetivamente o direito positivo, não é difícil perceber a finalidade buscada pelo instituto da incapacidade. Como já referido, o problema central de que trata a teoria geral do direito civil consiste na valoração dos atos de autonomia privada - ou, o que seria mais exato dizer, dos efeitos por eles produzidos (nas situações jurídicas subjetivas). ${ }^{25}$ No caso de pessoas que, por força da idade ou de certas condições intelectuais ou psíquicas, não dispusessem do discernimento necessário para compreender quais repercussões jurídicas adviriam dos atos por elas praticados, concluiu o legislador que tais efeitos deveriam ser negados pelo ordenamento. $O$ instituto da (in)capacidade se presta justamente a essa finalidade: indicar a (in)validade dos atos praticados por certo indivíduo e, em última instância, informar se é possível que esses atos produzam efeitos juridicamente vinculantes. ${ }^{26}$

Por que o discernimento do agente foi levado em conta para esse propósito? A criação de efeitos jurídicos pela autonomia privada é alvo de certa desconfiança por parte do ordenamento, já que a juridicidade desses efeitos significa, em última análise, que o aparato estatal de coerção deve garantir sua observância. ${ }^{27} \mathrm{~A}$ desconfiança é menor nos casos em que os efeitos são ditados pela lei (atos-fatos jurídicos e atos jurídicos em sentido estrito) e maior nos casos em que os particulares determinam o conteúdo dos efeitos criados (negócios jurídicos). ${ }^{28}$ Para produzir efeitos juridicamente coercíveis e vinculantes, é preciso que o agente possa responder pelas repercussões que provocará para si mesmo e para as pessoas com quem se relaciona. Repita-se: não há liberdade juridicamente tutelada sem responsabilidade. A vida em

21 Afirma-se, assim, a configuração complexa da fattispecie prescricional, a qual não se confunde com o simples decurso do tempo, mas "se identifica com o decorrer do tempo, segundo o regime jurídico para ele expressamente ditado" (MONATERI, 2009, p. 26. Tradução livre).

22 Essa abordagem é proposta novamente por Câmara Leal: "A incapacidade absoluta, privando o incapaz da administração de sua pessoa e bens, por inaptidão, cria-lhes uma situação de inferioridade na vida civil, tornando-os impotentes para a defesa de seus interesses, e daí a proteção que a lei lhes assegura, na salvaguarda desses interesses, concedendo-lhes favores especiais, entre os quais o da isenção prescricional. Esse benefício representa, pois, uma justa medida de tutela, supletiva da incapacidade e acauteladora dos interesses do incapaz" (LEAL, 1959, p. 162).

23 A expressão, ainda tomada por empréstimo pela doutrina atual, significava, no direito romano, a perda do status libertatis, do status civitatis ou do status familiae, de modo a excluir ou restringir a capacidade do sujeito (CHAMOUN, 1968, p. 48).

24 Afirma-se com frequência, por exemplo, que o Estatuto da Pessoa com Deficiência procurou "evitar os termos 'incapacidade' e 'interdição', que geravam estigma desnecessário às pessoas com deficiência mental ou intelectual” (OLIVEIRA, 2016). Tal concepção parece ter atingido foro internacional; na França, por exemplo, afirma-se que o termo "pessoa protegida" substituiu a palavra "incapacidade", que era "julgada humilhante" (MALAURIE; AYNĖS, 2016, p. 257).

25 Segundo Perlingieri, toda situação jurídica é efeito de um fato, natural ou humano, juridicamente relevante (PERLINGIERI, 2008 p. 669). No direito pátrio, cf. SOUZA, 2015b, p. 2-5.

26 Assim, por exemplo, Pietro Perlingieri define a capacidade de fato (capacità di agire) como a "idoneidade do sujeito para desenvolver a atividade jurídica que diz respeito aos seus próprios interesses, ou seja, a atitude de manifestar vontades dirigidas a adquirir e exercitar direitos ou a assumir (mas, de regra, não a adimplir) obrigações jurídicas" (PERLINGIERI, 2014, p. 143). Ainda mais clara é a lição de Alberto Trabucchi, que define a capacidade de agir como "a atitude de um sujeito de pôr em prática validamente atos idôneos a incidirem sobre situações jurídicas das quais é titular" (TRABUCCHI, 2015, p. 281).

27 Cf. SOUZA, 2016 , p. 134 e ss.

28 A diversidade de regime jurídico, baseada no papel desempenhado pela vontade em cada tipo de ato, é ressaltada por Salvatore Pugliatti: "a tutela da vontade se comporta de maneira diversa em relação às duas categorias de atos (simplesmente) voluntários [para o autor, os atos jurídicos em sentido estrito] e dos atos de vontade [negócios jurídicos]: na verdade tal distinção, que tem valor apenas sob o perfil jurídico, impõese e se sustenta com referência à diversidade fundamental de postura da tutela jurídica" (PUGLIATTI, 1996, p. 55. Tradução livre). 
comunidade depende dessa íntima relação e, por isso, se o agente, por falta de discernimento, não for responsável, não poderá praticar atos juridicamente relevantes com liberdade plena. ${ }^{29}$

A comparação entre os regimes da validade negocial e da prescrição mostra-se útil por se tratar de institutos concebidos em ótica fundamentalmente estruturalista - e que costumam ser aplicados, por isso mesmo, com precisão quase cartesiana. Assim, por exemplo, se certo negócio ostenta um vício previsto em lei como causa de nulidade, afirma-se tradicionalmente que nada haveria a questionar: 0 ato seria privado de toda eficácia, em um raciocínio subsuntivo simples. ${ }^{30}$ Analogamente, se a lei veda que os prazos prescricionais corram contra os absolutamente incapazes, não caberia questionar o fundamento valorativo dessa norma nem cogitar de sua aplicação analógica a outras pessoas, pois o caráter excepcional da regra impediria esse tipo de interpretação. Quanto às invalidades negociais, porém, já se destaca atualmente seu fundamento valorativo, sustentando-se a possibilidade de modulação da eficácia de atos nulos à luz dos interesses envolvidos em concreto (SOUZA, 2017), e assim também na prescrição, a despeito da aparência algo matemática do instituto, parece haver espaço para uma análise funcional.

Além disso, a comparação entre invalidade negocial e prescrição importa para o presente estudo porque, com alguma frequência, o legislador opta por usar a incapacidade civil (destinada prioritariamente a determinar a validade da prática de atos da vida civil) como uma espécie de índice valorativo para outros institutos que, em princípio, não correspondem à sua função originária. Assim parece ocorrer com o art. 198, I, do Código Civil: embora as repercussões jurídicas do decurso do tempo não decorram, evidentemente, de negócio jurídico (nem de qualquer ato humano), muito menos se relacionem com um problema de validade negocial, aproveitou o codificador a categoria da incapacidade absoluta como um indicador do grupo de pessoas a que pretendia se referir - provavelmente porque, também para fins de impedimento e suspensão da prescrição, o discernimento do titular Ihe pareceu um critério relevante. ${ }^{31}$

Nesse caso, então, a próxima indagação deveria ser: se o absolutamente incapaz conta, em regra, com um representante legal para realizar atos em seu nome (inclusive atos de cobrança aptos a interromper os prazos prescricionais), não seria o caso de permitir a fluência da prescrição contra ele? De fato, no regime da validade negocial, o ato praticado pelo representante em lugar do absolutamente incapaz é plenamente válido e vinculante. Assim, sempre que a administração dos bens e direitos desse incapaz estiver confiada a um representante, não seria o caso de tratar o titular do direito como se capaz fosse, exatamente como ocorre em matéria de validade negocial? Essa solução não é incompatível com a natureza dos institutos. ${ }^{32}$ De fato, alguns países da família romano-germânica preveem expressamente a fluência da prescrição contra incapazes que se encontrem sob representação dos pais, tutores ou curadores. ${ }^{33}$ Além disso, no

29 Na lição precisa de Maria Celina Bodin de Moraes: "A consequência da capacidade é, como se sabe, a imputação de responsabilidade. A imputabilidade é a possibilidade de ser considerado, pelo direito, como o autor de seus próprios atos, devendo em consequência por eles responder. Quem não tem discernimento tampouco tem responsabilidade, e as sanções jurídicas são diferenciadas justamente com base nesta distinção. Ter discernimento é ter capacidade de entender e querer. Se o indivíduo for dotado desta capacidade, dela decorrem a autodeterminação e a imputabilidade (isto é, a responsabilidade)" (BODIN DE MORAES, 2010, p. 192. Grifo do original).

30 Para uma análise crítica dessa perspectiva, cf. SOUZA e SILVA, 2016, item 2.

31 Ao comentar a proteção dispensada aos absolutamente incapazes pelo art. 169 do CC 1916, por exemplo, Ferreira Coelho recorre à noção de discernimento: "Os loucos de todo gênero são também absolutamente incapazes, não têm, como os menores de 16 anos, o discernimento necessário para defender os seus direitos" (COELHO, 1933, p. 68). O autor prossegue em defesa da necessidade de proteção das pessoas sem discernimento para a legitimidade do exercício pessoal da autonomia patrimonial: "[...] o fim da sociedade é a garantia, o respeito dos direitos de cada um dos indivíduos que a constituem, protegendo os mais fracos e pondo os incapazes ao abrigo de prejuízos que lhes possam causar a falta de discernimento para se defenderem e aos seus direitos; é a tutela social sobre os fracos" (Ibid., p. 70).

32 Registra Caio Mário da Silva Pereira: "O caso dos incapazes, embora não seja peculiaridade nossa, não tem paralelo em alguns sistemas, como o alemão ou o português, quando o incapaz tem representante, pois que este é responsável com seus bens, se deixa causar prejuízo ao seu representado" (PEREIRA, 2016, p. 583).

33 Sobre a matéria, dispõe o Código Civil português: "Artigo $320^{\circ}$. 1. A prescrição não começa nem corre contra menores enquanto não tiverem quem os represente ou administre seus bens, salvo se respeitar a atos para os quais o menor tenha capacidade; e, ainda que o menor tenha representante legal ou quem administre os seus bens, a prescrição contra ele não se completa sem ter decorrido um ano a partir do termo da incapacidade. [...] 3. O disposto nos números anteriores é aplicável aos interditos e inabilitados que não tenham capacidade para exercer o seu direito, com a diferença de que a incapacidade se considera finda, caso não tenha cessado antes, passados três anos sobre o termo do prazo que seria aplicável se a suspensão se não houvesse verificado". Confira-se ainda a previsão do BGB: "§210. [...] 1. Se uma pessoa incapaz de contratar ou com capacidade limitada de contratar não tiver representante legal, então um prazo prescricional em seu benefício ou em seu prejuízo não pode acabar antes do término de seis meses após o momento em que a pessoa adquire capacidade ilimitada de contratar ou a falta de representação é sanada. Se o prazo prescricional for inferior a seis meses, o período especificado para a prescrição toma o lugar dos seis meses. [...]" (Tradução livre). 
direito brasileiro, autorizada doutrina critica severamente a isenção da prescrição contra os incapazes, uma vez que estarão, na normalidade dos casos, representados. ${ }^{34}$

Anteriormente à reforma do sistema das incapacidades, alguns estudos chegavam a defender, a despeito da redação legal, que o prazo prescricional começaria a fluir contra o maior interdito assim que Ihe fosse nomeado curador. ${ }^{35}$ Essa proposta era formulada para se evitar que, perdurando a incapacidade absoluta por toda a vida adulta, acabasse por se conferir uma exigibilidade perigosamente longa às pretensões do incapaz - que poderia, décadas após o surgimento da pretensão, surpreender a outra parte com o seu exercício. ${ }^{36}$ Esse problema parece ainda mais grave em um sistema como o brasileiro, no qual, embora exista um prazo geral de prescrição para os casos não expressamente previstos, não existe um prazo-limite máximo para os óbices à prescrição - diversamente do que ocorre em outros países por meio de figuras como o délai butoir, na França, ${ }^{37}$ e a Verjährungshöchstfrist, na Alemanha. ${ }^{38} \mathrm{~A}$ ausência desse limite permitia que, no direito pátrio, fosse possível um impedimento vitalício da prescrição. Melhor seria, assim, segundo essa corrente doutrinária, admitir a fluência da prescrição tão logo se iniciasse a curatela. ${ }^{39}$

Tal posição, contrária ao texto original do Código Civil, talvez tenha perdido seu argumento mais eloquente no regime atual, uma vez que, após a reforma das incapacidades, a única causa legal de incapacidade absoluta no direito brasileiro passou a ser o critério etário (e cessa, portanto, necessariamente com a maioridade civil, o que à primeira vista parece afastar o referido risco à segurança jurídica). No entanto, como se buscará demonstrar mais adiante, ainda é possível sustentar para certas pessoas com deficiência mental um óbice à prescrição similar àquele aplicável aos absolutamente incapazes. Nesse cenário, a proposta de se condicionar o fluxo da prescrição à representação não é despicienda e nem desprovida de sentido; ao contrário, parte do mesmo raciocínio aplicável à invalidade negocial - o que conduz a uma reflexão sobre o papel do discernimento do titular do direito sobre a fluência do prazo prescricional. Com efeito, se o discernimento, como se mencionou, está relacionado tanto à responsabilidade quanto à autorresponsabilidade do agente pelos efeitos produzidos em matéria de invalidade, qual seria sua relevância em matéria de impedimento da prescrição?

A noção de responsabilização do agente (in casu, do titular que permanece inerte no seu exercício) não parece oferecer uma explicação consistente em sede de prescrição, seja porque, como já se referiu, tem sido progressivamente abandonada a lógica de punição da inércia do titular, seja porque, em princípio,

34 Nesse sentido, critica Serpa Lopes a proteção dispensada aos incapazes em matéria de prescrição: "Nada obstante as dúvidas legadas pelo Direito romano, a prática e quase todas as legislações mantêm o princípio do não decurso da prescrição, em relação a menores e certos incapazes. [...] entendemos não se justificar o princípio, dada a assistência que devem ter esses incapazes" (LOPES, 1996, p. 578). Nesse sentido, cf. VALLE, 1918, pp. 91 e ss. Outros autores, porém, respondem que, mesmo havendo representação, a lei buscou dar aos absolutamente incapazes "maior assistência, prevenindo, assim, qualquer descuido ou desídia, mesmo de boa-fé, que por parte de seus ditos representantes lhes pudesse causar algum dano" (FISCHER, 1957, p. 499).

35 Nesse sentido, propõe Mirna Cianci: "A prescrição contra o incapaz não tem curso, como do referido dispositivo consta, apenas enquanto não Ihe tenha sido nomeado curador. Após essa providência, o interdito passa a ter quem por ele responda, na administração de todos os seus bens e interesses, razão que fundamenta o processo de interdição [...]. Entendimento diverso conduz a inusitada situação. O incapaz, na pessoa de seu representante legal, poderia aguardar, digamos, cinquenta anos para ingressar em juízo, pleiteando todos os efeitos pretéritos desde o fato, tornando-se perigosamente indefinido o prazo prescricional e criando insegurança no mundo jurídico, em razão da dificuldade criada ao demandado, especialmente na produção da prova contrária, surpreendido como seria pela propositura de demanda relativa a fatos dos quais, eventualmente, sequer teria memória" (CIANCI, 2006).

36 A crítica não é recente, tendo sido formulada já por Pothier: "o prazo da menoridade tem limites certos, ao passo que a demência de uma pessoa, durando normalmente toda a sua vida, poderá chegar aos 80 ou 100 anos, e a prescrição, tão necessária para a tranquilidade dos cidadãos, muitas vezes seria suspensa durante todo esse tempo [...]" (POTHIER, 2002, p. 611). O problema, como se vê, seria de prolongado impedimento da prescrição (pois, com a morte do titular, a prescrição voltaria a fluir para os créditos do espólio), e não de imprescritibilidade propriamente dita, como tantas vezes se afirmou antes da reforma do sistema das incapacidades (ilustrativamente, cf. LÔBO, 2009, p. 349).

37 Prevê o Code francês: "Artigo 2.232. O adiamento do ponto de partida, a suspensão ou a interrupção da prescrição não podem ter como efeito levar o prazo de prescrição extintiva para além de vinte anos a contar do nascimento do direito" (Tradução livre). Como a doutrina pondera, "buscando a segurança e se inspirando no direito alemão, nos princípios europeus do direito dos contratos e no anteprojeto de reforma do direito das obrigações e da prescrição, quebrando a jurisprudência da Corte de Cassação, o artigo 2.232 estabelece esse prazo-amortecedor de vinte anos 'a contar do dia do nascimento do direito"; trata-se, porém, de um "amortecedor furado" (butoir troué), pois não se aplica a uma infinitude de prazos específicos, tais como certas ações indenizatórias por danos morais, ações reais imobiliárias, ações de estado, etc., que tendem à imprescritibilidade (MALAURIE, AYNĖS; STOFFEL-MUNCK, 2016, p. 712. Tradução livre).

38 O §199 do BGB prevê prazos prescricionais máximos (Verjährugnshöchstfristen) de dez ou trinta anos, conforme a natureza da pretensão e, em alguns casos, do conhecimento ou desconhecimento por culpa grave da pretensão por parte do titular.

39 A proposta recebe elogios da doutrina: "A posição está fundamentada no princípio da exercibilidade da pretensão, exposta por Pontes de Miranda. [...] É fascinante a tese, e está repleta de razoabilidade. Do contrário, cai por terra toda a filosofia que impõe a prescrição. Apesar de tudo, não se encontram precedentes jurisprudenciais que a confortam" (RIZZARDO; RIZZARDO FILHO, e RIZZARDO, 2015, p. 75-76). 
os efeitos jurídicos da prescrição parecem prejudicar mais o próprio titular do que qualquer outra pessoa..$^{40}$ Por outro lado, e esta parece ser a melhor explicação, a noção de autorresponsabilidade incutida no critério do discernimento oferece um parâmetro hermenêutico útil para o regime jurídico da prescrição, ${ }^{41}$ pois é razoável supor que a ordem jurídica decidiu eximir dos efeitos da prescrição as pessoas que não têm consciência das consequências que sua inércia produz contra seu próprio interesse. ${ }^{42}$ Evita-se, assim, um cenário em que se deixa o incapaz sofrer o prejuízo para, em seguida, sujeitá-lo "aos azares de uma ação regressiva, com risco de esbarrar na insolvência do representante” (PEREIRA, 2016, p. 583).

No entanto, se tais considerações são procedentes, como parecem, deveriam também explicar uma dúvida fundamental em matéria de prescrição e incapacidade que salta aos olhos do intérprete pela simples leitura do texto legal: por qual razão o art. 198, I, do Código Civil trata apenas do absolutamente incapaz, deixando de lado a incapacidade relativa? De fato, se o fundamento último do impedimento da prescrição é a falta de discernimento típica dos incapazes, a ponto de afastar a autorresponsabilidade pelos efeitos negativos de sua própria inércia, não deveriam também os relativamente incapazes estarem incluídos na previsão legal? A questão é pouco abordada pela doutrina, que vê a exclusão do relativamente incapaz com a mesma naturalidade com que afirma a necessidade de "proteção" do absolutamente incapaz. ${ }^{43}$ Não se pode, porém, aceitar a escolha legislativa como puro arbítrio desprovido de conteúdo valorativo; cabe, em vez disso, investigar os indícios valorativos contidos na norma em comento.

Em análise cuidadosa, o fundamento para a exclusão da incapacidade relativa do titular do direito como causa impeditiva do curso da prescrição parece estar na crença de que o relativamente incapaz teria ingerência muito maior sobre o exercício da pretensão do que o absolutamente incapaz, na medida em que realiza pessoalmente os atos da vida civil, simplesmente dependendo da intervenção de um assistente para a maior parte deles (ao passo que o menor impúbere não realiza nenhum ato pessoalmente) ${ }^{44}$ Essa concepção já recebeu severas críticas de autorizada doutrina, que diagnosticou sua falha: como os atos do relativamente incapaz são inválidos sem a intervenção do assistente, a crença no "maior poder de intervenção" do titular da pretensão sobre o seu exercício se revela falaciosa na maioria dos casos. ${ }^{45} \mathrm{Em}$

40 Como observa Mauro Tescaro, o não exercício do direito pelo titular não constitui ato ilícito, mas apenas um comportamento considerado "anômalo" pelo legislador; isso leva boa parte da doutrina a dizer que a inércia do titular corresponderia à inobservância de um ônus jurídico (e não a uma obrigação) (TESCARO, 2006, pp. 111-114). Cf., ainda, PUGLIATTI, 2011, pp.198 e ss. A associação ao ônus jurídico, já sustentada em outra sede (SOUZA, 2015-B, p. 20), apenas é refutada na doutrina italiana por autores que rejeitam a própria categoria do ônus, relata TESCARO, 2006 , p. 126.

41 De fato, o princípio da autorresponsabilidade diz respeito a "todas as hipóteses fáticas em que um sujeito, sem violar nenhum dever jurídico, e sem cometer nenhum ato ilícito, tem um comportamento que, embora sendo idôneo a produzir efeitos reflexos na esfera jurídica de outros sujeitos [...] é diretamente lesivo dos interesses do próprio sujeito agente, e pode ser considerado - ao menos genericamente - anômalo em face a um modelo de conduta normal ou ordinário [...]. Trata-se, além disso, de hipóteses fáticas em que é necessário proceder a uma ponderação de interesses contrapostos, já que uma expressa previsão legislativa ou [...] um raciocínio jurídico de mais amplo respiro evidenciam a impossibilidade de proceder ao sacrifício integral de um dos interesses de que se trata" (TESCARO, 2006, p. 126. Tradução livre).

42 Valiosa é a lição de Salvatore Pugliatti: "na base do conceito de responsabilidade está a ideia de liberdade, de tal modo que entre os dois termos se pressupõe uma certa ligação. [...] Pode-se, por isso, afirmar que o enquadramento sistemático do conceito de autorresponsabilidade resulta, nos seus termos maximamente genéricos, da relação entre liberdade, como possibilidade de tomar uma dada iniciativa e de assumir um dado comportamento em relação a um determinado interesse próprio, e a responsabilidade relativa. Sob esse perfil, pode-se afirmar que liberdade e autorresponsabilidade são termos correlativos; e se pode falar de um princípio da autorresponsabilidade privada, correlata à liberdade de querer" (PUGLIATTI, 2011, p. 198. Tradução livre). Note-se que, para o autor, a autorresponsabilidade estaria fundada, na generalidade dos casos, no princípio da culpa (ressalvados casos legalmente previstos de autorresponsabilidade objetiva). Outros autores entendem que a culpa não é um requisito necessário da autorresponsabilidade, a qual exigiria tão somente uma contribuição causal comissiva ou omissiva para o fato (TESCARO, 2006, p. 137-139). Esse viés objetivo, porém, não parece prejudicar a vinculação ora sustentada entre discernimento e autorresponsabilidade (como já se analisou brevemente, em matéria de responsabilidade civil, em SOUZA, 2017, item 1.2.1).

43 Por exemplo, Ferreira Coelho afirma que os menores de 16 anos apenas estarão protegidos contra os efeitos da prescrição até essa idade, "pois o tempo para a prescrição contra eles só correrá depois de completos os 16 anos, durante os quais são eles considerados absolutamente incapazes" (COELHO, 1933, p. 68). No mesmo sentido, cf. CARPENTER, 1958, p. 330

44 O motivo de não se proteger o relativamente incapaz foi sutilmente explicado por Clóvis Beviláqua ao comentar a opção do BGB e do Código Civil português por permitir a fluência da prescrição contra absolutamente incapazes sob curatela: "Estes dois códigos atenderam a ponderações feitas por alguns autores, quanto ao impedimento da incapacidade. Entendem esses escritores que, tendo os incapazes seus representantes, não há razão para colocá-los a salvo da prescrição, pois, se esta os prejudicar, terão ação contra o representante desidioso, para ressarcir o prejuízo. Mas, incontestavelmente, é mais bem avisado o legislador que não expõe os absolutamente incapazes, que nenhuma intervenção têm nos atos jurídicos praticados por seus pais ou tutores, aos azares dessa indenização falível" (BEVILÁQUA, 1980, p. 297. Grifou-se).

45 Pondera Carvalho Santos, em tom crítico: "Não se pode deduzir daí que seja possível ao relativamente incapaz, mesmo sem a assistência de seu representante, fazer interromper a prescrição, por ter ele intervenção própria nos fatos da vida civil, como parece a muitos, por isso que é bem lembrar que se ele tem interferência própria nesses atos, a validade destes fica dependente justamente da assistência legal, o que, em última análise, equivale a dizer que sem a devida assistência ele incapaz não poderá intervir utilmente para fazer interromper a prescrição. Ele fica desamparado e, neste caso, sem ter contra quem intentar ação regressiva. O prejuízo é inevitável" (SANTOS, 1986, p. 391-392). 
termos práticos, o relativamente incapaz depende ordinariamente tanto da vontade do assistente quanto o absolutamente incapaz depende do representante ${ }^{46}$ Aliás, sobretudo no caso do menor púbere, não é incomum que a assistência prestada por seus pais se converta em uma mera continuação da representação que exerceram até os seus dezesseis anos. Com efeito, a gradação de discernimento concebida pela lei acaba gozando de pouco reconhecimento social (ainda que a intervenção pessoal do menor seja reputada como requisito de validade dos seus atos). ${ }^{47}$

Sobre esses problemas relativos à assistência do relativamente incapaz, novas considerações serão feitas mais adiante. Por ora, importa destacar que parece ínsita à ratio legis subjacente ao art. 198, I, do Código Civil a concepção de que o relativamente incapaz pode suportar melhor as consequências de sua própria inércia do que o menor de dezesseis anos (RIZZARDO, 2011, p. 192). Tal entendimento mostrase coerente com a disciplina da invalidade negocial, em que se estipula que os atos do relativamente incapaz desprovidos da atuação do assistente são meramente anuláveis: a vontade do relativamente incapaz é mais valorizada pela ordem jurídica do que a do menor impúbere, seu discernimento é reputado menos reduzido. ${ }^{48}$ Ainda que os mencionados impedimentos práticos para que o relativamente incapaz faça valer seu direito sem a participação do assistente não permitam solucionar a questão apenas com base no discernimento, parece legítima, neste ponto do estudo, a conclusão parcial de que também para a incapacidade relativa o critério do discernimento foi levado em conta na construção do sistema da prescrição.

Contra essas explicações, poder-se-ia argumentar que, se a inércia do titular do direito não é a verdadeira fonte dos efeitos da prescrição, nenhum atributo subjetivo desse titular deveria ser relevante para a fluência do prazo prescricional. Como, porém, a prescrição consiste, sob certa perspectiva, em mecanismo de contraeficácia do exercício da pretensão, considera-se que esse mesmo exercício é capaz de interrompê-la. ${ }^{49}$ Nessa perspectiva, o comportamento do titular do direito seria irrelevante como pressuposto da prescrição (funcionando apenas como um critério posterior que permitiria a interrupção) e, assim, talvez não se pudesse creditar o impedimento da prescrição contra o incapaz a qualquer critério subjetivo seu (tal como seu discernimento quanto às consequências nocivas de sua inação). ${ }^{50}$ Semelhante abordagem, porém, traduz um estudo compartimentalizado do fenômeno da prescrição, como se a fluência do prazo prescricional e sua interrupção fossem questões orientadas por valores e finalidades diversas. Ao contrário, parece mais consentâneo com o sistema enxergar o inteiro regime da prescrição como um esforço legislativo de se conciliarem interesses contraditórios, buscando a todo tempo definir qual será merecedor de tutela.

46 Veja-se a descrição do exercício de atos por pessoa maior de idade sujeita a curatela na doutrina francesa: "O ato é desempenhado pelo incapaz, com a intervenção do curador sob a forma de assistência, quer dizer, em geral, sua participação efetiva no ato, no momento em que ele é praticado. O curador pode também dar sua autorização antecipadamente; esta deve ser especial a um ato determinado, pois uma autorização geral de fazer todos os atos seria equivalente à supressão da incapacidade" (MALAURIE; AYNĖS, 2016, p. 290. Tradução livre).

47 Para além da dependência instituída pelo legislador, a doutrina ainda ressalta uma dependência fática, sendo comum, nos casos de filhos de pais separados, que ocorra uma indevida "ingerência do ascendente não guardião, que usa de sua influência sobre o amor e a dependência afetiva do seu filho" para impedí-lo de praticar determinados atos (MADALENO, 2015, p. 727).

48 "Assim, se o menor púbere quer praticar ato jurídico, [...] a lei já considera a sua vontade e respeita sua manifestação volitiva. O legislador dá validade ao ato jurídico emanado de sua vontade, o qual pode aperfeiçoar-se e ganhar eficácia se o incapaz comparecer assistido por seu representante [sic], que dá sua anuência àquele negócio" (RODRIGUES, 2007, p. 42). Assim também é em ordenamentos estrangeiros, como na França, por exemplo, onde os atos celebrados pelo "menor dotado de discernimento" são reputados válidos desde que observados todos os requisitos formais, pois "a teoria geral dos atos jurídicos não pode limitar a atividade jurídica do menor dotado de discernimento que, por hipótese, tenha uma vontade consciente, suficiente, por conseguinte, para vinculá-lo" (MALAURIE; AYNĖS, 2016, p. 289. Tradução livre).

49 A perspectiva é defendida por Pier Giuseppe Monateri à luz do direito italiano, que preserva o princípio (vigente no ordenamento brasileiro até o advento da Lei n. 11.280/2006, que revogou o art. 194 do Código Civil) segundo o qual a prescrição não pode ser conhecida de ofício (art. 2.938 do Codice civile). Essa característica do instituto permite que o autor enquadre a prescrição entre as exceções substanciais e, com isso, a qualifique como mecanismo de contraeficácia de direitos subjetivos: "na espécie, realiza-se sim uma adequação entre fato e direito, no sentido mais rico da mera certeza das relações, limpando o campo das ações tardiamente interpostas por força da caducidade da acionabilidade da pretensão, mas como efeito de uma hipótese fática objetiva de contra-eficácia [fattispecie oggettiva di contro-efficacia], cuja função é aquela de determinar uma liberação do titular do comportamento devido da sua subordinação à pretensão de outrem, enquanto possa ser feita valer coativamente contra a sua vontade" (MONATERI, 2006, p. 30. Tradução livre). Parece adotar o mesmo posicionamento, no direito português, COSTA, 2016, p. 1120. Essa abordagem aparenta ainda ser aplicável, em larga medida, ao caso brasileiro, sobretudo após o advento do CPC/2015, cujo art. 10 passou a obrigar o juiz a consultar as partes sobre qualquer matéria que não tenha sido suscitada, inclusive aquelas cognoscíveis de ofício, resgatandose assim boa parte do caráter dispositivo que se conferia à prescrição no regime original do Código Civil. Nesse sentido, antes da revogação do art. 194 do Código Civil, entendia Barbosa Moreira que a prescrição consistia em exceção material (MOREIRA, 2002, p. 153).

50 A correlação entre a inércia do titular como requisito do curso prescricional e as causas obstativas da prescrição é destacada, dentre outros, por PERLINGIERI, 2014, p. 429 
Nesse sentido, salta aos olhos a constatação de que as causas suspensivas, interruptivas e impeditivas da prescrição, normalmente consideradas questões menores no interior do instituto, revelamse, em verdade, seu ponto nodal. De fato, talvez ainda mais importante do que saber a extensão do prazo prescricional seja saber contra quem ele corre, a partir de quando corre e em que circunstâncias pode ser interrompido ou suspenso. ${ }^{51}$ Grande parte do potencial funcional do instituto da prescrição, assim sendo, parece estar consignado nas causas de suspensão, interrupção e impedimento, que se tornam protagonistas do estudo do fenômeno prescricional, como instrumentos privilegiados para a promoção dos interesses merecedores de tutela em cada hipótese concreta. ${ }^{52}$ É a partir dessa compreensão que se passa ao estudo de algumas possíveis propostas de solução para os problemas envolvendo incapacidade e prescrição, como se verá a seguir.

\section{0 credor incapaz ou com discernimento reduzido e sua proteção quanto ao termo inicial dos prazos de prescrição e decadência}

Até este ponto da exposição, buscou-se demonstrar de que modo a consciência do incapaz a respeito das consequências negativas da sua inércia no exercício de uma pretensão se presta a tornálo autorresponsável por tais consequências - em outros termos, de que modo o discernimento do titular condiciona a fluência do prazo prescricional. Embora se tenha alcançado a conclusão parcial de que a diferença de discernimento entre absolutamente e relativamente incapazes é um dos motivos para que o art. 198, I, do Código Civil apenas aluda aos primeiros, outros problemas restaram pendentes. De uma parte, indaga-se se o fato de incapazes contarem com um representante ou assistente não deveria ter alguma relevância para o impedimento da prescrição. Por outro lado, questiona-se o problema prático da dependência do relativamente incapaz em relação ao seu assistente para exercer validamente qualquer ato de cobrança de seu direito. Finalmente, é preciso apurar em que medida o critério do discernimento pode, ou não, justificar o impedimento da prescrição contra pessoas com deficiência mental após a reforma legislativa que passou a reputá-las como capazes.

Cabe, aqui, um esclarecimento prévio. Embora existam problemas de prescrição relativos ao incapaz na posição de devedor (a favor de quem corre a prescrição), os quais serão abordados mais adiante, neste ponto da investigação o interesse estará centrado no incapaz que ocupa a posição de credor, isto é, de titular do direito (contra quem corre a prescrição). Note-se, aliás, que, por economia de linguagem, tem-se recorrido aos termos "credor" e "devedor" para indicar qual polo da relação jurídica é ocupado pelo incapaz. ${ }^{53}$ Tais termos pertencem, no rigor técnico, ao campo dos direitos de crédito, âmbito em que a influência do decurso do tempo costuma mostrar-se mais clara. ${ }^{54}$ Contudo, como se sabe, também os direitos absolutos se sujeitam à prescrição (DANTAS, 2001, p. 341). Essa simplificação de linguagem, embora algo intuitiva, não deve traduzir erro teórico.

51 Como destaca Mauro Tescaro no direito italiano, "as questões relativas ao início e à suspensão do decurso da prescrição [...] mereceriam - a nosso ver - atenção bem diversa daquela que lhes é dedicada, dada a sua fundamental importância para a economia do instituto, tanto sob o perfil prático quanto sob aquele teórico" (TESCARO, 2006, p. 5). Por sua vez, Pier Giuseppe Monateri sustenta que até mesmo o tão propalado requisito da inércia "não é um elemento autônomo da hipótese fática [da prescrição], mas se identifica com a falta de um dos atos de interrupção [...]" (MONATERI, 2009, p. 26. Tradução livre).

52 A esse propósito, já se observou a tendência, nas Cortes europeias, de se construir "um modelo de prescrição todo peculiar no qual os prazos de prescrição e decadência são concebidos como legítimos, mas também como potenciais obstáculos ao acesso dos indivíduos a uma tutela efetiva, com a consequente necessidade para os juízes nacionais de proceder caso a caso a uma aplicação dos próprios prazos prescricionais e de decadência respeitosa ao parâmetro da razoabilidade" (LONGOBUCCO, 2012, p. 953-954. Tradução livre). Frise-se ainda a advertência de Mauro Tescaro sobre a necessidade de se reconstruírem as regras sobre o decurso do prazo prescricional "do modo mais coerente possível não apenas com a complexiva regulamentação ditada em tema de prescrição, mas também com os princípios gerais do ordenamento com os quais tal regulamentação pareça suscetível de interferir, como se pode dizer, especialmente, para o princípio da autorresponsabilidade" (TESCARO, 2006, p. 7).

53 Fala-se aqui em credor e devedor tendo-se por referência cada prestação específica, sem se ignorar a complexidade do fenômeno obrigacional - tema já abordado, com farta referência bibliográfica, em SILVA, Rodrigo da Guia. Em busca do conceito contemporâneo de (in)adimplemento contratual: análise funcional à luz da boa-fé objetiva. Revista da Advocacia Geral da União, vol. 16. Brasília: abr.-jun./2017.

54 A respeito, já se anotou que, embora não seja privativa dos direitos de crédito, é "como causa de extinção das obrigações que a prescrição tem maior relevância" (LEITÃO, 2010, p. 111). Lembre-se ainda, na doutrina pátria, a crítica de Rodrigo Xavier Leonardo (2010, p. 116) ao fato de o Código Civil aludir apenas a pretensões obrigacionais em matéria de prescrição. 
Outra nota preliminar necessária a esta investigação diz respeito ao objeto de incidência da prescrição - se o próprio direito, a ação ou a pretensão. Trata-se de longeva controvérsia, em grande parte voltada a justificar a irrepetibilidade do pagamento realizado após a perda de exigibilidade do débito. ${ }^{55} \mathrm{~A}$ discussão, porém, revela pouco interesse prático, diante da já minudente disciplina que as codificações dispensam tanto ao problema da prescrição quanto à própria obrigação natural, bem como dos muitos acréscimos feitos pela doutrina, não raro à revelia da lei. No sistema italiano, por exemplo, que prevê a extinção do próprio direito, ${ }^{56}$ autorizada doutrina não tardou a defender que, na verdade, extingue-se a pretensão ou, mais especificamente, a acionabilidade do direito (possibilidade de deduzir a pretensão em juízo). ${ }^{57}$ No sistema francês, que indica tanto o direito quanto a ação como objetos da prescrição, ${ }^{58}$ a doutrina se apega a esta última previsão, constante das normas que tratam do termo inicial dos prazos prescricionais. ${ }^{59}$ As soluções, como se afirmou, estão prioritariamente na demarcação do termo inicial da prescrição - e, portanto, nas suas causas obstativas.

As regras para a identificação desse termo inicial variam entre os ordenamentos estrangeiros, mas todos eles demonstram algum nível de preocupação com circunstâncias concretas que podem influenciar o exercício da pretensão. Alguns sistemas adotam parâmetros subjetivos para determinar o começo da fluência do prazo (como a ciência, pelo titular do direito, do fato que originou a pretensão, ou da pessoa que violou seu direito), ${ }^{60}$ ao passo que outros abandonam qualquer consideração subjetiva e adotam critérios objetivos (como a inexistência de óbice fático ou jurídico ao exercício, etc.). ${ }^{61}$ Embora cada ordenamento adote um critério distinto, nenhum deles se conforma com a mera lesão ao direito, isto é, com o surgimento da pretensão como critério bastante e suficiente.

55 Na doutrina italiana, aduz-se que "se a prescrição operasse no sentido de extinguir o direito, não mais se compreenderia a regra [...] segundo a qual não se admite a repetição daquilo que é espontaneamente pago em adimplemento de um débito prescrito" (GAZZONI, 2015 , p. 110. Tradução livre). No direito português, chega-se a afirmar que seria mais adequado "qualificar a prescrição como uma hipótese de transformação da obrigação civil em obrigação natural" (LEITÃo, 2010, p. 119).

56 Dispõe o Codice civile: "Art. 2.934. 'Extinção dos direitos'. Todo direito se extingue por prescrição, quando o titular não o exerce pelo tempo determinado em lei. [...]” (Tradução livre).

57 Cf., por exemplo, a lição de MONATERI, 2009, p. 3-7: "a tese da extinção do direito por intervenção da prescrição, embora tendo em sua vantagem a letra da lei, vai de encontro ao próprio regime codicístico [...]. A pretensão, portanto, não é algo autônomo ao direito, mas a concretização do conteúdo do direito, que o titular do mesmo endereça àquele que põe em prática um estado de fato contrário ao próprio direito. A pretensão, assim, pode ou não ser deduzida em ação, e tanto é assim que não raro ela é endereçada primeiramente e fora de uma relação processual". Conclui o autor que a prescrição não extingue a pretensão nem a ação, ou o direito, mas sim "a possibilidade de que essa pretensão seja deduzida na ação: a sua acionabilidade" (Tradução livre).

58 Dispõe o Code civil: "Artigo 2.219. A prescrição é um modo de extinção de um direito resultante da inação de seu titular durante certo lapso de tempo". Ao tratar, porém, do prazo geral de prescrição e dos prazos especiais (arts. 2.224 e ss.), o legislador francês afirma expressamente que as ações "prescrevem".

59 Confira-se, ilustrativamente, a lição de MALAURIE, AYNĖS e STOFFEL-MUNCK, 2016, p. 705: "A prescrição liberatória extingue a ação judicial do credor. Ela deve ser distinguida de outros prazos que afetam a existência de um direito".

60 Dispõe o $\$ 199$ do BGB: "[...] O prazo prescricional regular começa, desde que nenhum outro prazo prescricional seja definido, com o fim do ano em que: 1. a pretensão surge e 2. o credor toma conhecimento ou deveria tomar conhecimento, sem negligência grave, das circunstâncias motivadoras da pretensão e da pessoa do devedor" (Tradução livre). Assim também o artigo 2.224 do Code francês: "As ações pessoais ou mobiliárias prescrevem em cinco anos a contar do dia em que o titular de um direito conheceu ou deveria conhecer os fatos que lhe permitiram exercê-lo" (Tradução livre). Particularmente quanto ao sistema francês, afirma-se que, após uma progressiva valorização, pela jurisprudência, da ignorância do direito como causa obstativa (quando decorrente de causa razoável), a tese foi apoiada também legislativamente, embora se leve em conta mais "uma impossibilidade objetiva de conhecer do que a ignorância pessoal do credor" (CARBONNIER, 2004, p. 2522. Tradução livre). A redação atual do art. 2.224 decorre da reforma legislativa de 2008, que uniformizou a tendência normativa anterior ao estipular um "point de départ 'glissant", como reconhece a doutrina: "Ao dizer 'aurait dû connaître', a lei recua ainda mais o ponto de partida, a fim de moralizar a prescrição em face da brevidade do novo prazo de prescrição extintiva do direito comum, mas tendo por inconveniente um risco de discussão interminável perante os tribunais" (MALAURIE; AYNĖS; STOFFEL-MUNCK, 2016, p. 711. Tradução livre).

61 Dispõe o art. $306^{\circ}$ do Código Civil português: "1. O prazo da prescrição começa a correr quando o direito puder ser exercido; se, porém, o beneficiário da prescrição só estiver obrigado a cumprir decorrido certo tempo sobre a interpelação, só findo esse tempo se inicia o prazo da prescrição [...]". No mesmo sentido, o art. 2.935 do Codice italiano: "A prescrição começa a correr a partir do dia em que o direito pode ser feito valer" (Tradução livre). Particularmente quanto ao direito italiano, afirma-se que "a possibilidade jurídica de exercício do direito determina a decorrência da prescrição, ao passo que não releva a simples impossibilidade de fato (por exemplo, a ignorância inculpável do próprio crédito, ou então o fato de que os pressupostos do direito sejam objeto de contestação judicial [...]). Esta pode apenas suspender o decurso do termo nos casos taxativamente previstos pelos arts. 2.941 e 2.942, ou por leis especiais" (ROSELLI, 2009, p. 494. Tradução livre). Registre-se, no ponto, que a previsão da suspensão da prescrição contra menores e interditos no referido art. 2.942 do Codice de 1942 representou um avanço em relação ao anterior Código de 1865 (art. 2.145), o qual somente assegurava o direito de regresso (em crítica à previsão anterior, cf. PUGLIESE, 1924, p. 134-138). A doutrina afasta a relevância das impossibilidades de fato para o exercício do direito, ressalvados certos casos que se tornam juridicamente relevantes, como a coação perpetrada contra o titular do direito (GAZZONI, 2015, p. 114). Em perspectiva crítica quanto a essa restrição às impossibilidades de fato, cf. TESCARO, Mauro. Decorrenza della prescrizione e autoresponsabilità, cit., p. 11-12. Por outro lado, alguns autores adicionam à noção de impossibilidade a "extrema dificuldade" de exercício (cf. PERLINGIERI, 2014, p. 429). 
O codificador brasileiro de 2002, por sua vez, adotou a tese da pretensão, noção atribuída a Bernhard Windscheid ${ }^{62}$ e traduzida do termo alemão Anspruch ${ }^{63}$ Dispôs o Código Civil pátrio no art. 189 que, "violado o direito, nasce para o titular a pretensão, a qual se extingue pela prescrição", sem prever nenhuma norma específica sobre o início da contagem do prazo. Abriu margem, com isso, à crença de que o termo inicial da prescrição coincidiria sempre com o surgimento da pretensão. ${ }^{64}$ Embora tal escolha pareça simplificar o caminho, na verdade apenas fomentou maior confusão doutrinária e jurisprudencial. Isso porque, como eventualmente se concluiu, a aquisição do direito, o surgimento da pretensão e o termo inicial do prazo prescricional podem corresponder a três momentos cronológicos distintos, e, a rigor, apenas o último é relevante para a tutela dos interesses das partes ${ }^{65}$ Assim, mesmo após o advento do Código Civil de 2002, continuam sendo comuns as referências a teorias tradicionais que buscam, à semelhança dos sistemas estrangeiros, modular o início do curso do prazo prescricional. Contudo, sem a necessária ordenação, que apenas pode ser promovida pela norma positiva, muito incertas são as concepções veiculadas por cada uma dessas construções.

A mais conhecida delas é, provavelmente, a teoria da actio nata, expressão oriunda do brocardo actioni nondum natae non praescribitur ("as ações ainda não nascidas não prescrevem"). Trata-se de elaboração teórica atribuída a Savigny, que a desenvolve longamente em seu Tratado de Direito Romano, associando-a à própria lesão do direito. Para que haja prescrição, afirma Savigny, é preciso "um direito sério, atual e suscetível de ser reclamado na justiça"; é preciso, em seguida, "uma violação do direito, que determina uma ação do titular" (SAVIGNY, 1858, p. 288). A elaboração do autor sobre o direito romano justifica a supervalorização do papel da ação, herdada pelo direito francês até os dias atuais. Não se põe em questão a figura, de certo modo intermediária, da pretensão. ${ }^{66}$ Essa noção de actio nata, porém, destoa radicalmente dos muitos empregos conferidos à expressão pela doutrina brasileira. Há autores que aludem à teoria para indicar que apenas começaria a correr a prescrição com a ciência do lesado a respeito do fato lesivo, ${ }^{67}$ ou ainda com a possibilidade de ajuizamento da ação pelo titular do direito. ${ }^{68}$

A rigor, porém, a ciência da lesão ao direito e a possibilidade de exercício da pretensão correspondem a dois sistemas totalmente distintos de estipulação do termo inicial dos prazos prescricionais, frequentemente designados, respectivamente, como sistemas subjetivo e objetivo. ${ }^{69} \mathrm{O}$ sistema subjetivo (que valoriza a ciência da lesão) costuma ser adotado em um contexto de redução dos prazos prescricionais, como aquela

62 Cf. WINDSCHEID, 1862, p. 89 e ss.

63 Dispõe o §194 do BGB: "[...] O direito de exigir de outrem um fazer ou não fazer (pretensão) sujeita-se à prescrição" (Tradução livre). Como pondera Barbosa Moreira, o art. 189 do Código Civil brasileiro teve como fonte inspiradora o referido dispositivo alemão: "O elemento comum a ambas as normas reside em identificar a pretensão como o objeto da prescrição. Ao contrário do legislador brasileiro, porém, o alemão animouse a oferecer uma definição da pretensão (Anspruch), cujo núcleo consiste num 'direito de exigir'”, a suscitar diversas controvérsias doutrinárias (MOREIRA, 2002, p. 150). Para o autor, no direito brasileiro, a pretensão deve ser compreendida não como mera exigência do conteúdo do direito, mas como exigência fundada, como "poder de exigir", surgido ordinariamente após a violação (Ibid., p. 149-150).

64 Este, aliás, foi o objetivo deliberado do Projeto do Código Civil ao tratar da pretensão, tendo-se rejeitado as emendas em contrário, como registra ALVES, 1986, p. 151-152.

65 Assim, sustentam, por exemplo, GUEDES e LGOW (2014, p. 1855): "O elemento fundamental [...] para o cômputo do prazo prescricional deve ser a possibilidade de que o direito seja exercido, e não a sua violação pura e simples".

66 Ainda hoje se afirma na doutrina francesa: "É tradicionalmente admitido que não é o próprio crédito que é extinto [pela prescrição], mas a ação na justiça do qual ele era munido" (CARBONNIER, 2004, p. 2516. Tradução livre). Afirma-se, por vezes, que "todos os direitos e todas as ações são em princípio prescritíveis" (TERRÉ; SIMLER; LEQUETTE, 2013, p. 1511), sem qualquer referência à pretensão.

67 Assim, por exemplo, SILVA (2008, p. 57): "A teoria da actio nata tem por conteúdo o entendimento de que o prazo prescricional ou decadencial somente se inicia com a ciência da lesão pelo interessado". Ironicamente, Savigny definia a noção de actio nata como uma violação do direito totalmente independente da ciência pelo titular: "pouco importa que o titular do direito dela tenha ou não conhecimento" (SAVIGNY, 1858, p. 289. Tradução livre).

68 Por todos, confira-se a lição de Orlando Gomes, que sustenta a aplicabilidade da actio nata no direito brasileiro: "A prescrição é o modo pelo qual um direito se extingue em virtude da inércia, durante certo lapso de tempo, do seu titular, que, em consequência, fica sem ação para assegurálo. São seus pressupostos: a) a existência de um direito atual, suscetível de ser pleiteado em juízo; b) a violação desse direito; a actio nata, em síntese" (GOMES, 2008, p. 444). Em outra passagem, confere o autor sentido diverso à teoria: "A regra intuitiva é de que seu início [do prazo prescricional] coincide com o instante em que a pretensão pode ser exercida (actioni nondum natae non praescribitur). A dificuldade reside, porém, na fixação desse momento" (Ibid., p. 447). Esse último sentido se difundiu na doutrina francesa contemporânea, na qual se afirma que, mesmo antes da reforma legislativa de 2008, a jurisprudência já reconhecia que "a prescrição tinha como ponto de partida o dia em que o credor podia agir, o que se dizia por vezes em latim: 'actioni non natae non currit praescriptio'” (MALAURIE; AYNĖS; STOFFEL-MUNCK, 2016, p. 711). No mesmo sentido, TERRÉ et alii (2013, p. 1526).

69 "Pelo sistema objetivo, o prazo começa a correr assim que o direito possa ser exercido e independentemente do conhecimento que, disso, tenha ou possa ter o respectivo credor. Pelo subjetivo, tal início só se dá quando o credor tenha conhecimento dos elementos essenciais relativos ao seu direito. O sistema objetivo é tradicional, sendo compatível com prazos longos; o subjetivo joga com prazos curtos [...]" (CORDEIRO, 2015, p. 202). 
que ocorreu por ocasião da reforma do BGB ocorrida em 2001. ${ }^{71}$ O sistema objetivo, por sua vez, reputase mais adequado em um contexto de longos prazos prescricionais, sendo adotado, por exemplo, pelo direito português. ${ }^{71} \mathrm{O}$ Código Civil brasileiro, surpreendentemente, contentou-se em não adotar qualquer sistema, desperdiçando uma oportunidade valiosa de avançar na disciplina do termo inicial da prescrição ${ }^{72}$ (como, aliás, o próprio CDC já fizera, mais de uma década antes, ao adotar o sistema subjetivo para a prescrição da pretensão indenizatória). ${ }^{73}$ Diante desse niilismo legislativo, a doutrina permanece invocando a antiquada noção de actio nata, já muito modificada e constantemente reinventada em formulações que buscam sanar, na medida do possível, a lacuna criada pela necessidade hermenêutica de se considerar as circunstâncias concretas do titular. ${ }^{74}$

A doutrina alude ainda ao brocardo contra non valentem agere non currit praescriptio ("contra quem não pode agir não corre a prescrição"). ${ }^{75}$ Com origens tão imprecisas quanto a teoria da actio nata, o adágio já pode ser encontrado na obra de Pothier, que o associa à não fluência da prescrição enquanto pendente de verificação a condição suspensiva ou o termo inicial do direito. ${ }^{76}$ No entanto, também o sentido do princípio contra non valentem agere foi sendo modificado com o tempo. Muitos autores passaram a compreender que se trataria de motivos de força maior que impediriam o ajuizamento da ação pelo titular do direito; outros cogitam de certas imposições legais que obstam o exercício da pretensão por certo período de tempo; alguns ainda admitem que tanto certos impedimentos de fato quanto determinados óbices de direito, a teor do brocardo, justifiquem a não fluência do prazo prescricional. ${ }^{77}$ A reforma legislativa ocorrida no Código Civil francês, em 2008, adotou o princípio em uma acepção ampla, positivando tendência

70 Sobre a reforma do BGB, comenta Menezes Cordeiro: "pela reforma, a prescrição inicia-se com o surgimento da obrigação em jogo e pelo conhecimento, por parte do credor, das circunstâncias originadoras da obrigação visada, salvo desconhecimento grave negligente [...]. Abandonouse o sistema anterior, objetivo, a favor de um sistema subjetivo. Em suma: houve uma alteração efetiva na Filosofia da prescrição, mostrando que é possível um Direito civil personalizado, mesmo quando haja que enfrentar problemas postos pela massificação atual" (CORDEIRO, 2015, p. 182).

71 A esse propósito, afirma Menezes Leitão: "Em relação ao início do prazo de prescrição, a lei determina que este só se verifica a partir do momento em que o direito puder ser exercido (art. $306^{a}, n^{\circ} 1$ [do Código Civil português], ou seja, a partir do momento em que o credor tem a possibilidade de exigir do devedor que realize a prestação devida" (LEITÃO, 2010, p. 116-117).

72 Veja-se a crítica precisa de Rodrigo Xavier Leonardo: "[...] o Código Civil perdeu a oportunidade de estabelecer causas de impedimento ao curso prescricional em moldes mais abertos para determinadas situações de grave vulnerabilidade, e de difícil verificação do surgimento da pretensão e do polo passivo contra a qual ela se dirige. A disciplina dos impedimentos ao curso da contagem do tempo na prescrição praticamente repetiu o Código Civil de 1916 [...]. Numa sociedade marcada por relações tão impessoais, os resquícios do discurso sobre o direito romano na chamada teoria da actio nata precisariam encontrar válvulas de alteração conforme as situações dos envolvidos" (LEONARDO, 2010, p. 116).

73 A ciência da lesão é, com efeito, adotada pelo legislador consumerista: "Art. 27. Prescreve em cinco anos a pretensão à reparação pelos danos causados por fato do produto ou do serviço prevista na Seção II deste Capítulo, iniciando-se a contagem do prazo a partir do conhecimento do dano e de sua autoria".

74 Ilustrativamente, em posição intermediária, José Fernando Simão defende a aplicação da actio nata (aparentemente adotada pelo codificador) apenas para pretensões que não decorram de relações contratuais: "A noção de Savigny pela qual a actio nata surge com a violação e independe do conhecimento do surgimento da pretensão revela-se absolutamente adequada. Conforme frisou-se anteriormente, todo o estudo da actio nata por Savigny passa pelo inadimplemento das obrigações contratuais, e não extracontratuais. [...] Para fins de responsabilidade extracontratual, a noção de Savigny de actio nata deve ser afastada. Em se tratando de direito disponível no qual não houve negligência ou inércia do titular do direito que desconhecia a existência do próprio crédito e, portanto, a possibilidade de exercício da pretensão, o prazo prescricional só se inicia com o efetivo conhecimento" (SIMÃO, 2013, p. 213).

75 Como relata Mauro Tescaro, a autoria do brocardo costuma ser atribuída a Bartolo de Sassoferrato, o qual, diversamente dos demais juristas medievais, tratou da matéria aludindo não apenas a impedimentos particulares do exercício dos direitos, mas em termos mais gerais; destaca-se, ainda, a relevância da doutrina canonística na elaboração do princípio, pois se considerava, então, "imoral" que o sujeito pudesse ser prejudicado pelo mero lapso temporal (odiosa praescriptio), e "inadmissível" que essa perda se produzisse sem que o titular tivesse tido a possibilidade, não apenas jurídica, mas também de fato, de fazer valer a pretensão (item non currit praescriptio ubi ius non redditur propter defectum iuris vel rei)" (TESCARO, 2006, p. 28-29).

76 Segundo Pothier, "o prazo da prescrição não pode começar a correr enquanto o credor não puder intentar sua demanda, porque não se pode dizer que ele tardou em intentá-la enquanto não lhe foi possível fazê-lo. Daí provém esta máxima: Contra non valentem agere, nulla currit praescriptio" (POTHIER, 2002, p. 608-609).

77 Leciona Serpa Lopes sobre o princípio contra non valentem: "As objeções feitas a esse apotegma fundam-se em não ter sido ele contemplado no elenco das causas suspensivas ou impeditivas da prescrição. Quando há disposição expressa de direito positivo, a regra 'contra non valentem' não oferece dificuldades. [...]. Nos países obedientes à norma [original] do Código Civil francês, diverge a doutrina, no tocante à aplicação da regra 'contra non valentem'. Destacam-se, então, três correntes: $1^{\mathrm{a}}$ ) a dos negativistas, isto é, os que acham motivos ponderosos para não aplicála por analogia; $2^{\mathrm{a}}$ ) os que a aceitam, tanto quanto se caracterize a força maior; $3^{\mathrm{a}}$ ) os que consagram a regra, se o impedimento versar sobre matéria de direito, repelindo-a, se consistir em matéria de fato" (LOPES, 1996, p. 581-582). 
jurisprudencial que já se verificava mesmo à míngua de previsão legal. ${ }^{78} \mathrm{E}$ a doutrina pátria também afirma ser necessário adicioná-lo ao rol de causas suspensivas e impeditivas. ${ }^{79} \mathrm{~A}$ muito defendida taxatividade desse rol não parece servir de obstáculo à aplicação da máxima, ${ }^{80}$ eis que essa taxatividade há de ser ressignificada para abranger o próprio princípio justificador de boa parte das causas ali elencadas. ${ }^{81}$

O princípio contra non valentem agere se revela de particular importância para a presente investigação, porque muitas vezes vem associada aos problemas da prescrição contra o incapaz. Na Itália e na França, por exemplo, já se afirmou que o impedimento da prescrição contra o titular incapaz decorre diretamente desse adágio. ${ }^{82} \mathrm{Na}$ jurisprudência francesa, admite-se que a deficiência mental consiste justamente em uma das hipóteses em que o titular do direito "não pode" agir, não sendo legítima, portanto, a fluência da prescrição contra ele. ${ }^{83}$ Qual é o fundamento, porém, do princípio contra non valentem agere no direito brasileiro? Para além da ampla aceitação doutrinária, ${ }^{84} \mathrm{o}$ adágio pode ser extraído, como princípio geral, da própria lógica que inspira as causas obstativas, inclusive (mas não apenas) em face do incapaz, como já se reconhece em outros países.$^{85}$ Aplica-se, portanto, mesmo a casos não previstos, por analogia das normas que regem essas causas. ${ }^{86}$ Nesse contexto, assume relevância central, sobretudo para o escopo do presente estudo, o art. 198, I, do Código Civil, que traduz, de modo emblemático, o papel do discernimento para a possibilidade de exercício da pretensão.

78 À luz da redação original do Código Civil francês, já lecionavam Aubry e Rau que o antigo artigo 2.251 não impedia a aplicação da máxima Agere non valenti, non currit praescriptio para suspender o curso da prescrição diante de obstáculos jurídicos ao exercício; o dispositivo significaria tão somente que "a condição pessoal de um indivíduo e as circunstâncias particulares de fato em que ele se encontra não podem jamais autorizar a admitir uma suspensão de prescrição que não tenha sido estabelecida por lei”; mesmo assim, os autores reconheciam ao juiz o poder de relevar os efeitos da prescrição consumada durante um obstáculo de fato (tal como uma inundação, uma invasão ou um cerco militar) se, após sua cessação, o titular tenha exercido imediatamente o direito (AUBRY e RAU, 1897, p. 499-500). No mesmo sentido, afirma-se que, "inspirada no adágio 'Contra non valentem agere non currit praescriptio' e no princípio da equidade, a jurisprudência se permitira dar a essa ideia um alcance mais geral, a despeito da disposição do artigo 2.251 (antigo) do Código Civil, que parecia reservar à lei a edição de causas de suspensão [...]. A lei de 17 de junho de 2008 fez do adágio uma regra de direito positivo" (TERRÉ et alii,2013, p. 1529. Tradução livre). De fato, após a reforma, passou a dispor o Código Civil francês: "Artigo 2.234. A prescrição não corre ou é suspensa contra aquele que está na impossibilidade de agir por força de um impedimento resultante da lei, da convenção ou da força maior" (Tradução livre). Analisando o dispositivo, afirmam MALAURIE, AYNĖS e STOFFEL-MUNCK, 2016, p. 714, que "as causas de suspensão têm uma história cíclica", e que, embora o Code tenha buscado, originalmente, restringir os poderes do juiz, a jurisprudência, "quase desde o alvorecer do Código, tinha restituído ao juiz um poder moderador ressuscitando a velha regra Contra non valentem agere non currit praescriptio [...], que o novo artigo 2.234 retoma quase literalmente" (Tradução livre).

79 Leciona Caio Mário da Silva Pereira: "Deve-se acrescentar uma outra regra que preside a suspensão da prescrição, dizendo-se que não corre na pendência de um acontecimento que impossibilite alguém de agir, seja como consequência de uma determinação legal, seja por um motivo de força maior, seja por uma convenção, regra que a jurisprudência francesa tem adotado, e que o velho adágio já traduzia: 'contra non valentem agere non currit praescriptio"' (PEREIRA, 2016, p. 584).

80 Para Serpa Lopes, "a regra contra non valentem agere inspira-se numa ideia humana, um princípio de equidade, e não pode deixar de ser reconhecida pelo juiz. Cabe, portanto, a aplicação analógica. Mesmo entendida como uma exceção à regra geral, esta não é de molde a encerrar num numerus clausus os casos de suspensão da prescrição, sobretudo quando se impõe interpretá-la com o espírito de equidade" (LOPES, 1996, p. 584). Na doutrina italiana, pondera Massimo Bianca não haver óbice à aplicação analógica das causas suspensivas, pois a tese contrária poderia ocasionar "um problema de constitucionalidade da norma onde esta não compreende casos nos quais a suspensão da prescrição parece igualmente justificada" (BIANCA, 2012, p. 580. Tradução livre).

81 Cite-se, ainda uma vez, a lição de Serpa Lopes: "Sendo a matéria omissa em nossa lei, deve o juiz buscá-la através das legislações dos povos cultos, e, a nosso ver, o Código Civil alemão, bem como o recente Código Civil grego, trazem princípios justos [...]. Com isto, evita-se o exagero do passado, com a aplicação abusiva da regra contra non valentem agere, e o exagero do extremo oposto presente, negando-a de um modo absoluto, ou recusando-a aos motivos de fato, que são tão imperativos e justos como os obstáculos de ordem jurídica" (LOPES, 1996, p. 584).

82 Na Itália, Alberto Trabucchi anota que o brocardo contra non valentem é o "princípio inspirador" da suspensão da prescrição, embora sustente que apenas se aplica aos casos expressamente previstos por lei (TRABUCCHI, 2015, p. 268). No direito francês, afirma Jean Carbonnier que a suspensão da prescrição "é governada pelas mesmas regras que em matéria de usucapião (notadamente, a jurisprudência faz aqui uso da máxima contra non valentem agere non currit praescriptio)" (CARBONNIER, 2004, p. 2515. Tradução livre). Particularmente sobre a incapacidade como causa obstativa, afirma-se que o art. 2.235 do Code traduz uma "aplicação particular clássica" do adágio, embora afaste a regra em caso de prestações periódicas (TERRÉ et alii, 2013, p. 1530)

83 Tem-se entendido que deve o juiz perquirir se a enfermidade mental de que sofria o titular "antes da instauração de um regime legal de proteção não constituía para ele uma impossibilidade absoluta de agir” (VENANDET et alii, 2016, p. 2651-2652. Tradução livre).

84 Nesse sentido: PEREIRA, 2016, p. 584; LOPES, 1996, p. 584; e, na doutrina mais atual, GUEDES e LGOW, 2014 , p. 1855

85 Como Leciona Reinhard Zimmermann em perspectiva comparatista do direito europeu, a regra "'agere non valenti non currit praescriptio' também requer que a prescrição não corra contra um credor que esteja sujeito a uma incapacidade. O exemplo paradigmático é o menor. [...] As considerações a seguir aplicam-se, mutatis mutandis, a pessoas que carecem da capacidade de ingressarem em relações jurídicas porque são enfermas da mente" (ZIMMERMANN, 2004, p. 134. Tradução livre).

86 Vale notar, no ponto, que, para a metodologia civil-constitucional, pouco importa a diferença entre analogia legis e juris: "a interpretação é sempre analógica, vez que, a rigor, não se procede por identidade entre norma e fato, mas por semelhança entre as fattispecie abstratas previstas nas normas e o fato concreto. [...] frequentemente, a normativa a aplicar é fruto de coligações entre mais disposições, ou entre fragmentos de disposições, de modo que não se saberia falar de 'precisa disposição' ou de analogia legis ou ainda de analogia iuris" (PERLINGIERI, 2014, p. 114. Tradução livre). 
Assim, ao menos no que diz respeito ao discernimento prejudicado do titular do direito (por força de idade ou de condição de saúde), o brocardo parece aplicável ${ }^{87}$ - sempre ponderado, evidentemente, com as circunstâncias do caso concreto, ${ }^{88}$ como já tem reconhecido a doutrina civil-constitucional. ${ }^{89}$ Tão consolidado é esse entendimento que, em matéria de decadência, cujo curso, via de regra, não pode ser interrompido, suspenso ou impedido, também a norma do art. 198, I, encontra aplicação (art. 208 do Código Civil). Em se tratando, portanto, de direito potestativo titularizado por pessoa com discernimento reduzido, a ser extinto pela decadência, todas as propostas hermenêuticas ora desenvolvidas parecem aplicáveis. Por maioria de razão, em matéria de prescrição, onde se reconhece um rol extenso de causas suspensivas e impeditivas, há de se perquirir se o titular da pretensão se encontrava, ou não, impedido de exercê-la.

De volta aos problemas específicos enunciados anteriormente, a máxima contra non valentem parece oferecer respostas promissoras. Retome-se, primeiramente, o caso do credor relativamente incapaz. Verifica-se, de fato, uma incongruência no sistema brasileiro, que submete o relativamente incapaz aos efeitos regulares da prescrição, embora não lhe permita agir validamente em nome próprio e sem assistência. Essa incongruência já constava no Código revogado e foi mantida na codificação atual. ${ }^{90}$ Resta evidente o prejuízo ao credor relativamente incapaz que, por qualquer motivo, estiver desassistido. Notese ainda que, se é certo que o ato do relativamente incapaz sem assistente se reputa meramente anulável e não nulo (art. 171, I, do Código Civil), esse abrandamento da invalidade não implica automaticamente uma maior aptidão para interromper o fluxo da prescrição: não apenas um ato de cobrança realizado apenas pelo incapaz estará sempre sujeito à anulação, como, em muitos casos, a falta temporária do assistente pode obstar, na prática, a própria realização da cobrança (basta pensar que, para ajuizar ação de cobrança, além de todas as dificuldades práticas, o relativamente incapaz que não tenha assistente dependerá da nomeação de um curador especial, na forma do art. 72 do CPC). Como já criticou a doutrina, - legislador parece se conformar com um cenário em que só resta ao incapaz "cruzar os braços, apelando em tempo para o juiz, a fim de que lhe nomeie um tutor que o venha salvar do prejuízo próximo" (SANTOS, 1986, p. 392).

Nessas circunstâncias, parece razoável supor que, estando o credor relativamente incapaz, por qualquer que seja o motivo, desprovido de assistente legal, sua situação será tal que não autoriza a fluência da prescrição. ${ }^{91}$ Nesse caso, está-se diante de impossibilidade jurídica para a realização do ato que

87 Na França, afirma-se, por exemplo, que a ignorância do direito pelo titular obsta a prescrição se corresponder ao "esquecimento causado por uma enfermidade mental", mas se ressalta, por outro lado, o caráter assistemático da jurisprudência, que, em vez de colocar todos os credores em uma situação idêntica a salvo da prescrição, protege apenas certos titulares em concreto, "levando-se em conta todas as circunstâncias que o impediram de agir a tempo" (CARBONNIER, 2004, p. 2522)

88 Como aduz Mauro Tescaro, a regra contra non valentem tem o mérito de destacar a necessidade "de uma equilibrada ponderação entre os interesses contrapostos, e, particularmente, entre o interesse do titular do direito sujeito à prescrição de poder exercitar a sua pretensão por mais tempo possível, de um lado, e o interesse da contraparte a adquirir tão logo possível a possibilidade de refutar legitimamente o adimplemento, por outro lado" (TESCARO, 2006, p. 115).

89 "Como visto, casos há em que o exercício da pretensão antecede qualquer espécie de lesão ao direito. Afora essas situações, ou a exigibilidade do direito coincidirá com a sua violação, ou será posterior. A rigor, há vários fatores capazes de impedir que a pretensão seja exercida desde o instante em que o direito é violado. Definir tais fatores contribuirá na fixação do momento em que a prescrição, nesses casos, começa a correr. Muitas vezes, o que será necessário determinar é o momento em que o titular da pretensão teve conhecimento da violação, pois até então ele estava impossibilitado de exercê-la" (GUEDES e LGOW, 2014, p. 1851).

90 Relata Carvalho Santos as críticas dirigidas ao projeto do Código Civil de 1916: "O projeto estabelecendo que a prescrição não corre contra os absolutamente incapazes, exclui a suspensão dela quanto aos relativamente incapazes. Este preceito, justo como regra, não deve ser absoluto, isto é, deve sofrer uma exceção no caso em que o incapaz relativamente não tenha representante legal e para o tempo em que dele estiver privado, pois que será injusto permitir que a prescrição corra contra aquele que não tem quem defenda o seu direito" (SANTOS, 1986, p. 391).

91 Tal entendimento se extrai, em certa medida, já das lições de Pothier: "A prescrição não corre contra os menores, mesmo que eles tenham tutor. Não pela regra contra non valentem agere non currit praescriptio, porque tendo um tutor, este pode intentar a ação por eles; mas porque a proteção particular que os que estão nessa idade merecem, isso fez com que os menores fossem excetuados da Lei da Prescrição" (POTHIER, 2002, p. 610). A contrario sensu, parece decorrer daí a noção de que a proteção dos incapazes desprovidos de tutor decorre da regra contra non valentem, como o autor afirmava expressamente para os deficientes mentais, pessoas "ainda mais incapazes de vigiar pela conservação dos seus bens do que os menores, e o seu estado é digno de compaixão e da proteção das leis” (Ibid., p. 611). 
seria apto a interromper a prescrição. ${ }^{92}$ Vale notar que essa proteção mínima sequer resolve o problema, igualmente possível, de conflito de interesses entre o relativamente incapaz assistido e o seu responsável - mas, para esses casos, a responsabilização civil prevista pelo art. 195 do Código Civil e a nomeação de curador especial, admitida pelo art. 72 do CPC, parecem fornecer soluções razoáveis. Assim, a fluência dos prazos prescricionais em desfavor do relativamente incapaz deve ter como contrapartida inafastável a garantia, por parte do ordenamento, de que ele está, ao menos, devidamente assistido. Tal entendimento evita o cenário em que o relativamente incapaz desassistido, diante da inexistência de qualquer assistente a ser responsabilizado pela inércia, veja seu direito prescrever e sequer possa ser indenizado na forma do art. 195 do Código Civil. Por outro lado, nomeado novo assistente, ou cessada a incapacidade, devem ser regularmente retomados os prazos prescricionais.

Vale mencionar ainda, em matéria de decadência, outra regra de importância crucial para o regime jurídico da incapacidade relativa. Se o relativamente incapaz celebrar negócio sem a intervenção do assistente, o Código Civil prevê expressamente, em seu art. 178, III, que o prazo decadencial para anulação do ato apenas começa a contar da data da cessação da incapacidade. A norma cria impedimento específico para o curso do prazo decadencial (que ultrapassa a regra geral do art. 208 do Código Civil), a reforçar a tese que se acaba de sustentar, de que a incapacidade relativa não pode ser de todo excluída do rol de causas obstativas da prescrição e da decadência. A lógica subjacente à não fluência do prazo nesse caso parece ser certa presunção de atuação deficitária do assistente, o que impossibilitaria, na prática, que o incapaz fizesse valer em juízo seu direito à impugnação do ato anulável. ${ }^{93} \mathrm{~A}$ mesma lógica explica, com maioria de razão, a norma do parágrafo único do art. 119 do Código Civil, que prevê prazo decadencial de 180 dias após a cessação da incapacidade para que o representado pretenda a anulação do ato do representante em conflito de interesses (regra que se tem aplicado ao conflito de interesses entre o relativamente incapaz e o assistente, cuja atuação inadequada resta, então, evidente) (CAHALI, 2008, p. 194). Em ambos os exemplos, à luz da lógica já exposta, parece razoável supor que, tendo havido substituição do assistente antes do término da incapacidade, não mais subsistiria razão obstativa do prazo decadencial.

Quanto ao absolutamente incapaz, por outro lado, o adágio contra non valentem parece evidenciar certo exagero na previsão do art. 198, I: se o credor, menor impúbere, estava representado por seus pais ou tutor, talvez fosse melhor considerar, à semelhança dos sistemas alemão e português, que nada impedia o exercício da pretensão. ${ }^{94}$ Apenas se o menor tivesse permanecido sem representante durante algum tempo seria razoável admitir a suspensão da prescrição durante esse período, tornando a fluir o

92 Cf., em sentido contrário à viabilidade, de lege lata, da proteção ao relativamente incapaz desassistido: "No Código Civil alemão há uma regra protetiva do relativamente incapaz, desprovido de representante legal, que suspende a consumação da prescrição até seis meses após a nomeação do assistente (art. 206). A solução, todavia, não pode ser adotada entre nós, porque nosso Código não contém norma equivalente e, em matéria de suspensão e interrupção da prescrição, só à lei compete disciplinar" (THEODORO JÚNIOR, 2003, p. 218). Por força da parte final do revogado art. 194 do Código Civil, o autor entendia que nem ao juiz era dado proteger o relativamente incapaz nesses casos (o.l.u.c.). Também contra a proposta ora aventada, cf. RIZZARDO, RIZZARDO FILHO e RIZZARDO, 2015, p. 58. Com enfoque crítico, também aduzia Carvalho Santos: "Suponhamos que um relativamente incapaz, um menor entre 16 e 21 anos, por exemplo, não tenha no momento um representante legal, por não ter pais vivos e nem tutor nomeado. Correrá e se consumará a prescrição contra ele? O Código alemão prevê a hipótese e dispõe que a prescrição que contra eles correr não se consumará senão depois de seis meses da nomeação do assistente (art. 206). [...] A omissão do Código [Civil brasileiro] não pode ser suprida com eficácia, em hipótese alguma, de modo a evitá-lo" (SANTOS, 1986, pp. 391-392). O dispositivo do BGB a que aludem os autores corresponde ao atual §210.

93 De fato, a explicação tipicamente invocada em doutrina para a escolha legislativa da cessação da incapacidade como termo inicial da decadência nesses casos é a de que "o incapaz não tem aptidão para postular, pessoalmente, a anulação do negócio jurídico, o que somente pode fazer após sua cessação” (PEREIRA, 2016, p. 537), como se fosse possível presumir a inação do assistente no lapso temporal entre a realização do ato (momento ordinariamente indicado como termo a quo da decadência do direito à impugnação) e a cessação da incapacidade.

94 Em perspectiva comparatista sobre o direito europeu, pondera Reinhard Zimmermann que, embora alguns países vedem o curso da prescrição contra os incapazes, "pode-se dizer, contudo, que [essa regra] passa do limite. Pois um menor normalmente tem um representante adulto (como um genitor ou um guardião) capaz de litigar em seu favor. Assim, pode-se discutir que o menor requer proteção apenas em casos nos quais, por alguma outra razão, ele se encontre sem representante" (ZIMMERMANN, 2004, p. 134. Tradução livre). O autor reconhece que a escolha entre essas duas abordagens "não é fácil", destacando que uma outra forma de proteger o menor consiste em suspender a prescrição de sua pretensão contra o representante até a maioridade: 'Semelhante direito de ação contra o genitor pode ser um 'substituto ruim' para a pretensão da própria criança contra a terceira pessoa. Mas o melhor interesse do menor não pode nesse aspecto prevalecer sobre o dessa terceira pessoa, já que o sistema jurídico pode razoavelmente partir da presunção de que o pai ou guardião vai normalmente cuidar dos interesses do menor" (Ibid., p. 134-135. Tradução livre). 
prazo com a nomeação de novo representante. A opção legal, porém, foi inequívoca, ${ }^{95}$ e tal proposição não parece sustentável de lege lata, embora mais razoável do ponto de vista valorativo. No atual estágio do direito positivo brasileiro, embora pareça possível estender a previsão do art. 198, I, ao relativamente incapaz desassistido (a partir da máxima contra non valentem e sem sacrifício à taxatividade das causas de suspensão e interrupção, por força da interpretação analógica do rol normativo), o procedimento oposto - isto é, a negativa de aplicação da norma a certos casos de incapacidade absoluta - não parece legítimo. ${ }^{96}$

E também no que tange às pessoas acometidas de deficiência mental (no passado inseridas na redação original do art. $3^{\circ}$, II, do Código Civil e hoje reputadas plenamente capazes), o princípio contra non valentem pode oferecer respostas satisfatórias. Caso se considere a enfermidade uma impossibilidade fática de exercício da pretensão, torna-se possível sustentar a não fluência da prescrição contra a pessoa com deficiência, ao menos durante o tempo em que, por qualquer eventualidade, permaneça sem curador. ${ }^{97}$ Considerando, por outro lado, que a curatela no sistema atual deve ser restrita a atos específicos, não mais se admitindo a interdição total da pessoa com deficiência, ${ }^{98}$ eventuais atos não abrangidos pela sentença que nomeia o curador presumem-se compatíveis com o nível de discernimento da pessoa - logo, seu não exercício, quando forem necessários à tutela de um direito, enseja o curso regular da prescrição.

A recente reforma legislativa do regime das incapacidades, aliás, parece ter colocado as pessoas com deficiência mental, ao menos no que diz respeito à prescrição, em uma posição mais razoável. No regime anterior, encontravam-se elas incluídas na previsão do art. 198, I, do Código Civil, sem grande espaço para que o intérprete corrigisse, no caso concreto, eventual iniquidade decorrente do fato de que pessoa com alto grau de discernimento e regularmente representada por curador pudesse usufruir por anos ou até mesmo em caráter vitalício do benefício da prescrição obstada, através de uma interpretação desatenta aos diversos graus possíveis de enfermidades mentais. No sistema atual, tendo em vista que a prescrição corre, em princípio, regularmente contra essas pessoas, pode o intérprete ponderar, em concreto, os interesses envolvidos, verificando os casos em que o benefício da não fluência do prazo prescricional se justifica (em geral, apenas aqueles em que a pessoa tenha permanecido sem curador).

O exemplo da curatela parcial das pessoas com deficiência mental remete ainda para o caso mais clássico, do pródigo, cuja incapacidade, como se sabe, está restrita a atos de disposição patrimonial (art. 1.782 do Código Civil). Em princípio, aplica-se ao pródigo o regime jurídico da capacidade plena para atos de qualquer natureza e o regime da incapacidade relativa se houver disposição patrimonial envolvida. ${ }^{99}$ No entanto, pode acontecer de, na prática, o não exercício pelo pródigo de uma pretensão implicar, por via transversa, disposição patrimonial - pense-se, por exemplo, no crédito que o pródigo nunca vem a cobrar do devedor como forma indireta de remissão da dívida. Nesse caso, para que se respeite a função

95 A doutrina majoritária afirma categoricamente a opção legislativa (por todos, cf. BARBOZA, BODIN DE MORAES e TEPEDINO, 2014, p. 374). No mesmo sentido, Silvio Rodrigues afirma que, se os absolutamente incapazes "são titulares de um direito, ainda que o não defendam mediante ação judicial, esta não prescreve, pois o prazo, que afinal a consumiria, só começa a fluir depois que ultrapassarem a incapacidade absoluta" (RODRIGUES, 2007, p. 338).

96 A crítica ao excesso legislativo na tutela dos absolutamente incapazes que se encontrem representados é tão antiga quanto o reconhecimento da impossibilidade de se superar a letra da lei nessa matéria. Ao argumento de que essas pessoas seriam protegidas porque não podem realizar pessoalmente os atos da vida civil, respondia Numa P. do Valle que o argumento "não convencerá a ninguém, visto como, se é verdade não poderem elas exercer pessoalmente tais atos, a lei já previu essa impossibilidade, colocando-as sob a autoridade de pessoas capazes, que por elas o exercem; prevendo, até, a responsabilidade dos que representem incapazes quando, por dolo ou negligência, derem causa a que uma prescrição se consume contra elas [...]. A disposição do $n^{\circ}$ I do art. 169 [do CC1916], não obstante a crítica que merece, há de ser aplicada, por isso que é lei" (VALLE, 1950, p. 91).

97 Assim sustentava Pothier: "Correrá o prazo da prescrição contra os mentecaptos? Estes ou estão ou não estão providos de curador. Quando não estão, encontram-se na regra contra non valentem agere etc., e não há dúvida de que a prescrição não pode correr contra eles" (POTHIER, 2002, p. 611).

98 O Estatuto da Pessoa com Deficiência restringiu o alcance da curatela aos atos de caráter patrimonial, restando a ela imunes os atos de natureza existencial (art. 85, caput e $\$ 1^{\circ}$ ). Além de expor as razões justificadoras da medida, o juiz deverá determinar pormenorizadamente os atos patrimoniais para os quais será necessária a intervenção do curador, fixando estritamente os limites da curatela (art. 755, I, do CPC). Admite-se a curatela para a generalidade dos atos de natureza patrimonial, mas para isso será necessária fundamentação detida da total impossibilidade de o curatelado praticar esses atos. A hipótese, contudo, deve ser excepcional, sob pena de desvirtuamento do caráter extraordinário da medida e subversão ao seu escopo protetivo. Para uma crítica a esta e outras alterações promovidas pela lei, cf. SOUZA e SILVA, 2016 , item 4.

99 Assim leciona SANTOS, vol. VI, 1986, p. 427, concluindo que a incapacidade do pródigo "é parcial e daí o nome de semi-interdito, com que costuma designá-lo algumas vezes". 
da curatela do pródigo (em geral associada à proteção do patrimônio familiar), ${ }^{100}$ parece razoável concluir que a inércia há de ser encarada como ato de disposição, a justificar a não fluência da prescrição. ${ }^{101}$ Notese que o curador do pródigo não está, em princípio, incumbido de promover por conta própria atos de interrupção da prescrição (ao contrário, o art.1.782 do Código Civil apenas cogita de sua atuação caso o pródigo tome a iniciativa de dispor do patrimônio ou demandar), de modo que nem o remédio indenizatório em face do representante parece assistir ao pródigo caso se sustente a fluência regular da prescrição contra ele. A solução mais consentânea com o sistema, por isso, parece ser a mesma disciplina casuística conferida às pessoas com deficiência mental, pois, em ambos os casos, a falta de discernimento do agente não está plenamente protegida pela técnica da curatela. ${ }^{102}$

\section{Mudanças supervenientes da capacidade do credor e sua relevância para a fluência de prazos de prescrição e decadência}

As perspectivas até o momento delineadas dizem respeito, fundamentalmente, à configuração do termo inicial dos prazos prescricionais e decadenciais em situações que envolvam pessoas que já eram incapazes ou tinham seu discernimento reduzido antes do início da fluência da prescrição ou da caducidade. Paralelamente a esse problema, porém, coloca-se a questão da relevância das mudanças supervenientes advindas à capacidade do titular do direito para o decurso desses prazos. A presente etapa do estudo buscará, então, esboçar possíveis respostas para problemáticas variadas cujo traço comum é a mudança superveniente da capacidade da pessoa.

O primeiro questionamento nessa seara diz respeito à definição de qual deveria ser o marco temporal para a configuração da causa impeditiva (ou suspensiva) do prazo prescricional, prevista pelo art. 198, I, do Código Civil, na hipótese em que o óbice à fluência do prazo se funda na falta de discernimento da pessoa do credor. ${ }^{103}$ Tal questão deu origem a expressiva controvérsia doutrinária, que remonta à promulgação do Código anterior e que subsistiu mesmo após o advento do vigente Código. ${ }^{104}$ Desde logo, cumpre destacar que a controvérsia travada em doutrina acerca da interpretação do art. 169, I, do CC 1916 (correspondente ao atual art. 198, I) permanece de considerável valia para o intérprete no atual panorama legislativo. Isso porque, como visto, embora o legislador reformista tenha suprimido a menção às pessoas com deficiência do rol de absolutamente incapazes, uma análise funcional do instituto da incapacidade civil permite visualizar a imprescindibilidade do discernimento e da concreta possibilidade de exercício para fins de deflagração dos prazos prescricionais e decadenciais.

A controvérsia cinge-se a duas principais linhas de entendimento. De uma parte, afirmava-se que a fluência da prescrição dependeria necessariamente da interdição do credor, pois somente a partir dessa

100 "A interdição por prodigalidade visa a defender o patrimônio familiar de dilapidações provocadas pela imoderação dos gastos e é sob tal fundamento que ainda hoje se procura defender a sua sobrevivência" (PEREIRA, 2017, p. 623).

101 Registre-se que a negligência na administração dos próprios interesses que acarrete ruína patrimonial também é considerada uma manifestação de prodigalidade, ao lado de gastos imoderados e desperdícios (SANTOS, vol. VI, 1986, p. 426).

102 A comparação parece oportuna, tendo em vista que a doutrina costuma aludir à falta de discernimento deste e até mesmo à sua debilidade mental como causa da prodigalidade. Veja-se a crítica contundente de Clóvis Beviláqua: "sabendo, pela psicologia dos pedidos de interdição, que, muitas vezes, eles abrigam a cobiça imoral de locupletar-se o impetrante com a fazenda do parente, ou o receio egoísta de ter de dar-lhe alimentos, deve [o jurista] afirmar: ou a prodigalidade é um caso manifesto de alienação mental, e não há necessidade de destacá-la para constituir uma classe distinta de incapacidade, pois entra na regra comum; ou tal não é positivamente, e não há justo motivo para feri-la com a interdição" (BEVILÁQUA, 1976, p. 96-97). Nesse sentido, entende Caio Mário da Silva Pereira que não são adequadas para o caso do pródigo "nem a abstenção total dos negócios da vida civil nem a liberdade de movimento que lhe dê pasto à tendência imoderada para o perdularismo. Todavia, se o pródigo é portador de enfermidade mental, incide na incapacidade por essa razão. Fora daí não parece conveniente conservar a inabilitação específica. [...] Espero mesmo que no futuro venha a ser eliminada, como já ocorreu no BGB [...]. Enquanto persistir, o texto legal tem de ser interpretado restritivamente, nos casos em que comprometa a fortuna" (PEREIRA, 2016, p. 241-242).

103 A menção restrita à pessoa do credor faz-se de especial importância porque, diferentemente do que sucede a propósito do art. 197 do Código Civil, a razão subjacente ao art. 198 do Código é a proteção do credor ao qual falte discernimento ou possibilidade de exercício da sua pretensão. Pertinente, neste ponto, o esclarecimento de THEODORO JÚNIOR, 2003, p. 235: "O art. 198, ao contrário do anterior, somente se ocupa de um dos sujeitos da relação material que pode ser afetada pela prescrição. Enquanto o art. 197, para suspender a prescrição, arrola pessoas que devem ocupar, indistintamente, as duas posições da relação jurídica, o art. 198 só se aplica em favor de certos credores. O óbice à prescrição, portanto, favorece apenas as pessoas nele arroladas quando são credoras, ou seja, quando se coloquem como titulares da pretensão".

104 Assim afirmam BARBOZA, BODIN DE MORAES e TEPEDINO, 2014, p. 374. 
medida se configuraria a incapacidade justificadora do impedimento ou da suspensão. ${ }^{105}$ Subjazia a tal corrente a noção de que a interdição seria imprescindível à caracterização da incapacidade civil, de modo que antes da decisão judicial não seria possível reconhecer alteração no status personae. A interdição teria, portanto, efeito constitutivo da incapacidade do interditando, o que justificaria o curso regular de eventual prazo prescricional em seu desfavor até a prolação da decisão.

O mérito dessa proposição teórica (particularmente no tocante à promoção da segurança jurídica formal) ${ }^{106}$ não ocultava os efeitos negativos dessa visão excessivamente formalista. Com efeito, não se pode descuidar da percepção de que o déficit no discernimento e a impossibilidade fática de exercício das pretensões constituem circunstâncias inexoravelmente associadas à análise concreta da pessoa nas relações jurídicas em que se faz presente. A restrição absoluta do estatuto legal protetivo da incapacidade exclusivamente para pessoas já interditadas acabava por ignorar um sem-número de hipóteses fáticas carentes de tutela específica pelo ordenamento jurídico.

Parecem ter sido tais ordens de preocupação que levaram a civilística a desenvolver a noção de incapacidade natural, com o que se pretendia fazer referência ao estado fático de déficit cognitivo prévio à decretação judicial da interdição. Desenvolveu-se, então, o entendimento de que a falta de discernimento da pessoa era logicamente anterior à interdição determinada por decisão judicial. Buscou-se, desse modo, possibilitar o reconhecimento de um estado de fato (denominado incapacidade natural) pré-existente ao estado determinado pela interdição (a chamada incapacidade legal), ${ }^{107}$ o que justificaria a aplicação do estatuto protetivo reservado às pessoas incapazes também em relação ao período anterior à sentença de interdição.

Sem embargo do mérito consistente em reclamar a atenção do intérprete para a tutela da pessoa em concreto, o desenvolvimento da noção de incapacidade natural acabava por confundir uma situação fática com uma qualificação jurídica. De fato, tanto o CC 1916 quanto o CC 2002, em sua redação original, eram claros ao prever que a incapacidade não era decorrência automática da deficiência mental, à qual deveria se somar a ausência de discernimento para que se pudesse reputar verificada a causa legal de incapacidade de exercício pessoal dos atos da vida civil. ${ }^{108} \mathrm{Em}$ suma, a tese da incapacidade natural buscava resolver um falso problema, pois mesmo diante da redação original do CC 2002 não havia razão para a então frequente identificação, em larga medida irrefletida, entre a deficiência mental e o estatuto da incapacidade. ${ }^{109} \mathrm{O}$ fundamental em matéria de incapacidade parecia ser, já antes da reforma legislativa, a identificação da concreta aptidão da pessoa humana para discernir e praticar pessoalmente os atos da vida civil, a permitir inclusive que a sentença de interdição reconhecesse fundamentadamente a invalidade de eventuais atos anteriores a ela caso já faltasse discernimento ao agente no momento de sua realização. ${ }^{110}$

105 "Não ocorrerá a prescrição contra o alienado não interdito? Entendemos que o alienado não interdito não está incluído no número dos que gozam desse favor, porque enquanto não interdito, o alienado não pode ser havido como absolutamente incapaz. Ademais, [...] tratando-se de uma derrogação de um princípio geral, a suspensão ou interrupção não se poderá estender à pessoa alienada, mas não interdita" (SANTOS, 1986, p. 409).

106 A menção crítica à segurança jurídica formal pretende demonstrar que o valor da segurança não se manifesta apenas na predeterminação estática de enunciados normativos, devendo-se concentrar na perspectiva dinâmica de conformação substancial aos valores constitucionais. A respeito, cf. TEPEDINO, 2008, p. iv.

107 V., por todos, GOMES, 2008, p. 154

108 Como já se sustentou em outra sede, destaca-se a importância de se "afastar a concepção, muito encontradiça em doutrina, segundo a qual o Código Civil em vigor, na sua redação original, confundia a deficiência mental com o próprio estatuto jurídico da incapacidade. A rigor, já no regime anterior se considerava amplamente que era a incapacidade o conceito relevante para o direito civil, de tal modo que a deficiência psíquica ou intelectual nada representava juridicamente sem que estivesse acompanhada do reconhecimento da eventual incapacidade civil dela decorrente, preferencialmente pela prova pré-constituída da interdição. A noção de incapacidade natural, invocada por alguns autores para representar a condição de fato da pessoa antes da constituição da dita incapacidade legal pela sentença de interdição, já não se considerava uma categoria jurídica autônoma no direito brasileiro" (SOUZA e SILVA, 2016, p. 19).

109 Afirma-se, inclusive, com frequência que "a principal contribuição do Estatuto do Deficiente constitui a desidentificação do deficiente com o incapaz. Trata-se do uso da lei na sua função promocional, com vistas a não discriminação" (MEIRELES, 2015, p. 178). No mesmo sentido, v. REQUIÃO, 2016.

110 Eis a conclusão de Caio Mário da Silva Pereira: "Alguns escritores fazem distinção entre incapacidades naturais e incapacidades arbitrárias, ou puramente legais; as primeiras correspondentes a um estado físico ou intelectual da pessoa; as segundas, ditadas por uma organização técnica das relações jurídicas. No direito brasileiro entendemos que não há lugar para a distinção. Toda incapacidade é legal, independentemente da indagação de sua causa próxima ou remota [...]. O que é necessário frisar é que, pelo direito brasileiro, a incapacidade resulta da coincidência da situação de fato em que se encontra o indivíduo e a hipótese jurídica da capitis deminutio definida na lei” (PEREIRA, 2016, p. 226-227). 
A repercussão de tais considerações sobre a disciplina da prescrição é das mais relevantes. Se a situação de vulnerabilidade da pessoa antecede a decretação judicial da interdição, e se a análise funcional da causa obstativa prevista pelo art. 198, I, do Código Civil revela o escopo de proteção da pessoa inapta ao exercício pessoal dos atos da vida civil, conclui-se que o óbice à fluência da prescrição contra o incapaz não depende da prévia sentença de interdição, mas sim da certeza inequívoca da ausência de discernimento específico. ${ }^{111}$ Desse modo, o credor incapaz será beneficiado pelo impedimento ou pela suspensão do prazo prescricional independentemente de estar, ou não, interditado, desde que demonstre o momento a partir do qual deixou de ter o discernimento mínimo necessário para o ato de interrupção da prescrição. ${ }^{112}$

Nesse cenário, a relevância da sentença de interdição se desprende da suposta constituição do estado de incapacidade ${ }^{113}$ e passa a centrar-se na facilitação da prova acerca da situação fática de ausência ou redução de discernimento. ${ }^{114}$ Com efeito, caso o incapaz tenha sido previamente interditado, bastará que alegue, para a suspensão do prazo prescricional em seu benefício, a incidência direta do art. 198, I, do Código Civil. Diversamente, caso o credor incapaz não tenha sido previamente interditado, competirá à sua defesa demonstrar, a fim de obstar a fluência do prazo prescricional, a ocorrência de situação fática de comprometimento do discernimento idônea a justificar a incidência do regime legal protetivo das incapacidades. ${ }^{115}$

Delineadas as perspectivas de configuração da causa impeditiva de fluência do prazo prescricional fundada na falta de discernimento (ou impossibilidade de exercício) em concreto pela pessoa, passa-se a investigar a repercussão que a incapacidade superveniente exerce sobre o prazo prescricional porventura já iniciado em desfavor do credor. Trata-se de questão de acentuada relevância, já que a caracterização da hipótese como suspensão ou interrupção repercute diretamente sobre o cômputo do prazo.

111 Nesse sentido: “a incapacidade de que se trata se dá ipso facto, tendo a sua decretação judicial efeitos meramente declaratórios, razão pela qual a regra ora comentada [art. 198, I] não deve depender da interdição, uma vez que a incapacidade se encontra relacionada com a superveniência da doença. Uma vez constatada a enfermidade, é a partir de então que o prazo prescricional deixa de fluir, ou sequer se inicia, independentemente da decretação judicial da interdição, devendo, apenas no caso de ausência desta, se fazer a prova do estado de incapacidade mental, para afastar a prescrição porventura alegada. Com efeito, não se pode admitir que o incapaz seja prejudicado com a consumação de prazo prescricional, em razão da negligência de seu curador, que não diligenciou o processo de interdição judicial em tempo hábil” (BARBOZA, BODIN DE MORAES e TEPEDINO, 2014, p. 375). Nesse sentido, v. LOPES, 1996, p. 579.

112 Aduz, a respeito, Pontes de Miranda: "contra a pretensão que nasceu depois da incapacidade absoluta, ou que resulta de direito que se transmitiu ao absolutamente incapaz, não começa de correr o prazo; contra a pretensão que nascera à pessoa, antes de se tornar absolutamente incapaz, suspende-se o curso do tempo: o que correu está corrido; continuará de correr quando cessar a incapacidade absoluta. A incapacidade absoluta existe pelo fato da incapacidade; portanto, a suspensão ocorre desde que tal fato se dá, independentemente de qualquer sentença, ou registro" (MIRANDA, 2013, p. 333). No mesmo sentido: CAHALI, 2008, p. 87

113 O caráter declaratório da sentença de interdição já era enfaticamente ressaltado por parte da doutrina tradicional, ainda que a falta de discernimento fosse por vezes confundida com a enfermidade mental: "Sendo a loucura a causa da incapacidade, por privar o demente do uso de sua razão e da aptidão para consentir, é evidente que essa incapacidade decorre de um fato anterior à interdição, e este apenas a reconhece e a declara. Não é, pois, a interdição que determina a incapacidade, mas, pelo contrário, é a incapacidade que determina a interdição. Isto posto, os loucos de todo o gênero, como os designa o Código, são absolutamente incapazes pelo fato da enfermidade mental, e, por isso, essa incapacidade existe e deve produzir as suas consequências jurídicas, quer o incapaz tenha sido interditado, quer não. A única diferença que se poderá notar é que o interditado tem na interdição a confirmação definitiva de sua incapacidade, bastando alegá-la para que seus efeitos sejam, desde logo, reconhecidos em juízo; ao passo que o não interditado carece produzir a prova de sua incapacidade" (LEAL, 1959, p. 163). No mesmo sentido, cf.RIZZARDO, RIZZARDO FILHO e RIZZARDO, 2015, p. 75.

114 Sobre a questão probatória, aduz Humberto Theodoro Júnior: "Não é necessário, para impedir a prescrição, que o alienado tenha sido interditado. A causa legal da incapacidade não é a sentença de interdição, é o déficit mental. O alienado é incapaz porque não tem condições psicológicas para a vida civil. A sentença apenas verifica e declara essa situação preexistente. [...] Por isso, o art. 198 prevê que a prescrição não corre contra os incapazes, sem fazer referência à respectiva interdição. Se a influência da interdição se faz sentir é no campo da prova tão somente. Se existe a sentença de interdição, a condição da incapacidade da pessoa está adrede demonstrada. Se não há a interdição, a alegação de incapacidade, para ser acolhida em juízo, e produzir os efeitos que lhe correspondem, dependerá de prova adequada do estado psíquico do sujeito de direito. Uma vez comprovada a incapacidade absoluta por falta de discernimento, a prescrição não fluirá contra o alienado mental, derive a prova da interdição, ou de outros meios de convicção" (THEODORO JÚNIOR, 2003, p. 236-237).

115 "Nem seria razoável fazer a incapacidade e seus efeitos depender da interdição, quando esta, confiada à iniciativa de determinados parentes do psicopata e do Ministério Público, pode ser descuidada e omitida, não sendo justo que o incapaz venha a sofrer as consequências de uma desídia para a qual não teria podido concorrer e contra a qual não dispunha de meios para impedir. Para nós, a [...] incapacidade civil absoluta se opera ipso facto, e a prescrição das ações de que é titular não corre contra ele, quer tenha sido pronunciada a sua interdição judicial, quer não, competindo-lhe, apenas, na ausência de interdição, fazer a prova de seu estado de incapacidade mental, para demonstrar a inexistência da prescrição, se, porventura, alegada" (LEAL, 1959, p. 164). 
Com efeito, caso se sustente que a incapacidade superveniente justifica a interrupção do prazo prescricional, a eventual cessação da capitis deminutio ${ }^{116}$ justificaria o início de um novo prazo, com a desconsideração de todo o período transcorrido até o advento da causa interruptiva. Não parece ser essa, porém, a disciplina concebida pelo Código Civil, por duas principais ordens de razão. A uma, porque a previsão contida no art. 198, I, do Código Civil engloba tanto o impedimento (óbice ao decurso inicial do prazo) quanto a suspensão (óbice ao prosseguimento do prazo já iniciado), o que se conclui não apenas pelo título da Seção em que se localiza o dispositivo ("Das causas que impedem ou suspendem a prescrição") como, sobretudo, pela constatação da identidade funcional entre o impedimento e a suspensão. ${ }^{117} \mathrm{~A}$ duas, porque a interrupção traduz medida acentuadamente mais nociva à confiança paulatinamente criada para o devedor no sentido de estabilização da relação sem o exercício da pretensão - confiança que faz pender cada dia mais em seu favor o juízo de merecimento de tutela. Tais considerações permitem concluir que a superveniência da incapacidade do titular justifica a suspensão (e não a interrupção) do prazo prescricional previamente iniciado; cessada a incapacidade, a prescrição retoma seu curso do ponto em que se paralisara. ${ }^{118}$

Faz-se pertinente destacar, a propósito da suspensão do prazo prescricional, que não somente a superveniência da incapacidade, mas igualmente a cessão do crédito ${ }^{119}$ e a sucessão do credor original capaz, ${ }^{120}$ têm o condão de suspender o decurso do prazo - desde que, por evidente, o novo titular do direito seja considerado incapaz. Desse modo, caso o credor originário venha a falecer e deixe como único herdeiro um menor impúbere, o prazo prescricional porventura iniciado em desfavor do de cujus será automaticamente suspenso, voltando a fluir somente por ocasião do atingimento da idade de 16 anos de idade pelo herdeiro. ${ }^{121}$

As precedentes considerações permitem analisar, por fim, os questionamentos criados especificamente pelo Estatuto da Pessoa com Deficiência. De início, coloca-se a questão: após o Estatuto, qual é o marco temporal que obsta a fluência da prescrição - a sujeição à curatela ou a falta de discernimento? Em que pese a aplicação de diploma legal recém-publicado, parece não haver maiores peculiaridades que justifiquem entendimento diverso ao exposto no início deste item acerca da generalidade das pessoas com discernimento reduzido ou impossibilitadas de exercer uma pretensão.

116 Em tal hipotética linha de entendimento, não faria sentido admitir o reinício do prazo no mesmo momento da verificação da falta de discernimento, pois de ato singular não se trata. Parece que mais adequado seria, portanto, recomeçar o prazo a partir do término da situação fática de incapacidade, aplicando-se o art. 202, parágrafo único, do Código Civil segundo a diretriz determinada pela interpretação teleológica do dispositivo.

117 De fato, não há diferença funcional entre causas impeditivas e suspensivas: "a lei cuida conjuntamente das causas que impedem ou suspendem a prescrição. A meu ver, fá-lo bem, pois não há mister de distinguir coisas de idêntica natureza” (RODRIGUES, 2007, p. 337).

118 "Se a prescrição já havia sido iniciada e depois ficou suspensa pela superveniência de uma incapacidade, cessada esta retoma a prescrição o seu curso, não, porém, reiniciando-o (como na interrupção), mas continuando do ponto em que ficara suspensa" (FISCHER, 1957, p. 500). O autor exemplifica: "Um demente tem a sua prescrição suspensa enquanto permanece nesse estado de insanidade mental. Se, porém, se recupera e volta a se tornar uma criatura normal, desde aí a prescrição começar a correr ou retoma o seu curso caso tenha sido suspensa depois de iniciada a sua trajetória" (Ibid., p. 500). No mesmo sentido, v. LEAL, 1959, p. 165.

119 "Em se tratando de menores ou outros incapazes, poderemos acrescentar que a cessão de um crédito feito a qualquer deles faz com que a prescrição deixe de correr [...].Verdadeira será, portanto, a seguinte conclusão: importa pouco, para os efeitos da suspensão da prescrição, que o menor ou o incapaz seja ou não desde o princípio o titular do direito, nada importando que a prescrição tenha começado a correr contra uma pessoa capaz, desde que o direito é transferido a um incapaz" (SANTOS, 1986, p. 410). No mesmo sentido, v. FISCHER, 1957, p. 540-544; LOPES, 1996, p. 579. Isso não legitima, por evidente, que uma cessão fraudulenta possa obstar o prosseguimento do prazo prescricional.Como adverte Antônio Luís da Câmara Leal, embora a incapacidade absoluta converter-se em causa suspensiva se o incapaz se tornar "titular da ação, depois de iniciada a prescrição, por lhe ter sido transferido o direito","não há dúvida que essa solução pode dar lugar à cavilação, servindo-se o titular do direito, em vias de prescrição, de uma transferência ou cessão simulada a um incapaz, como meio de impedir a prescrição. Mas, se a simulação ficar provada, a cessão se torna nenhuma e a prescrição se opera, a despeito do artifício" (LEAL, 1959, p. 165).

120 "A suspensão a proveito dos menores e dos interditados tem lugar, não somente no caso onde a prescrição começou a correr contra eles, mas ainda quando ela primeiro nasceu contra a pessoa de um maior o qual eles sucederam" (AUBRY e RAU, 1897, p. 492. Tradução livre). No mesmo sentido, cf., na doutrina pátria, THEODORO JÚNIOR, 2003, p. 236.

121 O exemplo remonta à lição de FISCHER, 1957, p. 500: "Aquela prescrição que se iniciara em vida do titular ficará suspensa desde o dia do falecimento dele e até que o herdeiro complete 16 anos de idade. Quando isso acontecer, a prescrição retomará o seu curso, não, porém, iniciando a contagem do prazo prescricional, mas continuando do ponto em que ficara suspensa". 
De fato, o escopo protetivo a que se fez reiterada menção não é exclusividade das causas legais de incapacidade, devendo ser estendido a todas as hipóteses em que a pessoa humana apresentar vulnerabilidade concreta que justifique tutela diferenciada por parte do ordenamento jurídico. Entender diversamente representaria, por parte do intérprete, inadequada postura de entregar ao legislador ordinário autêntico "cheque em branco" para delimitar (em caráter alegadamente exaustivo) as hipóteses em que a pessoa humana merece tutela diferenciada.

Assim, ainda que o legislador alegadamente tenha pretendido excluir as pessoas com deficiência psíquica ou intelectual do âmbito de abrangência do regime legal das incapacidades, faz-se necessário reconhecer-lhes a proteção do óbice à prescrição desde a constatação da ausência de discernimento. À semelhança do que se propõe para a generalidade das hipóteses de discernimento comprometido ou impossibilidade de exercer a pretensão, deve-se reconhecer que, após o advento do Estatuto da Pessoa com Deficiência, o marco temporal para impedimento ou suspensão do prazo prescricional coincide com o início da situação fática de vulnerabilidade tal como aludida, relegando-se à eventual decisão judicial fixadora de curatela mero caráter de facilitação probatória.

Isso significa, por outro lado, que algumas pessoas reputadas incapazes antes do advento do Estatuto da Pessoa com Deficiência poderão apresentar um grau de discernimento tal que não justifique nenhum óbice ao curso da prescrição no regime atual. Nesses casos, impõe-se a imediata cessação da incidência da disciplina protetiva das incapacidades. Uma advertência final, porém, parece necessária. $O$ advento da lei não poderá afetar o período em que o prazo prescricional tenha permanecido suspenso ou impedido (por exemplo, em decorrência de um regime de curatela integral do credor que, após a Lei de Inclusão, deverá ser adequado na forma de curatela parcial, e não mais justificará um óbice à prescrição). Deve a lei nova ter aplicação prospectiva, retomando-se o prazo prescricional a partir da sua entrada em vigor, sem prejuízo ao período em que o credor foi beneficiário da suspensão ou impedimento da prescrição. ${ }^{122}$

\section{Pretensão indenizatória do incapaz contra seu representante legal pela inércia em obstar ou arguir a prescrição}

Passa-se a analisar, doravante, os desafios interpretativos postos pelo art. 195 do Código Civil. O dispositivo prevê que "[O]s relativamente incapazes e as pessoas jurídicas têm ação contra os seus assistentes ou representantes legais, que derem causa à prescrição, ou não a alegarem oportunamente". A aparente simplicidade do enunciado normativo ressalta, todavia, a já mencionada necessidade de diferenciação do tratamento dispensado ao incapaz conforme a posição que o mesmo venha a ocupar na relação jurídica - a saber, se credor ou devedor da pretensão. Quanto à primeira hipótese, a norma prevista pelo art. 195 traduz-se em autêntica mitigação do rigor com que o legislador excluiu, em princípio, os credores relativamente incapazes do benefício de impedimento ou suspensão do prazo prescricional (conclusão que, como se viu, decorre, a contrario sensu, da menção limitada aos absolutamente incapazes no art. 198, I).

Percebeu-se, em síntese, que a mera existência de assistente não traduziria tutela plena dos relativamente incapazes, cuja particular vulnerabilidade (ainda que presumivelmente reduzida se comparados com os absolutamente incapazes) justificaria certo nível de tutela pelo ordenamento.

\footnotetext{
122 Assim entende, por exemplo, Antonio dos Reis Júnior: "Acredita-se que as hipóteses de situações subjetivas que, para sua formação, iniciamse na lei antiga e continuam na vigência da lei nova devem obedecer ao critério da retrospectividade. Por esta diretriz, e tomando como base o problema da prescrição, deve-se considerar que as pretensões das pessoas portadoras de deficiência mental, em qualquer grau, deixaram de ter o prazo prescricional interrompido a partir da vigência da lei nova. [...] Isso significa dizer que para todas as pessoas com deficiência mental, os prazos prescricionais permaneceram interrompidos durante a vigente da lei antiga, mas começaram a correr em 2 (dois) de janeiro de 2016 , por força da lei nova. Tal solução intermediária, anote-se, de modo algum ofende a garantia do direito adquirido ou do ato jurídico perfeito. Isso porque não havia, verdadeiramente, direito adquirido à imprescritibilidade, nem mesmo fato ou ato consolidado ao qual se pudesse qualificar como ato jurídico perfeito" (REIS JÚNIOR, 2016, p. 197).
} 
Pareceu justo ao legislador, então, em contrapartida à fluência regular dos prazos prescricionais contra tais pessoas, assegurar a elas pretensão indenizatória em face dos seus assistentes "que derem causa à prescrição" (nos termos do art. 195 do Código Civil). ${ }^{123} \mathrm{O}$ sistema restaria, assim, harmonizado no que tange à situação do credor incapaz: contra os absolutamente incapazes, não corre a prescrição (art. 198, I), razão pela qual sequer há de se cogitar de dano pela consumação da prescrição; diversamente, contra os relativamente incapazes, corre regularmente a prescrição, mas eles restaram resguardados pela possibilidade de demandar dos respectivos assistentes o prejuízo decorrente da desídia em interromper a prescrição - respeitada, em qualquer caso, a situação do devedor beneficiado pela prescrição, não se tendo adotado a antiquada figura da restitutio in integrum. ${ }^{124}$

Cumpre, porém, indagar acerca da situação do credor relativamente incapaz que não tenha assistente: seria possível vislumbrar a deflagração de responsabilidade civil em seu favor caso venha a ser prejudicado pela consumação da prescrição? Impõe-se a resposta negativa, por absoluta impossibilidade lógica. ${ }^{125}$ De fato, coerentemente com a proposta antes formulada, parece legítimo, nos casos em que se entenda cabível o impedimento da prescrição contra o relativamente incapaz, por estar ele, por qualquer motivo, desprovido de assistente, que não se fale em perdas e danos, já que sua situação seria análoga à do absolutamente incapaz. A contrario sensu, estando o relativamente incapaz assistido, a regra prevista pelo codificador é expressa: o assistente apenas poderá ser responsabilizado pela não interrupção da prescrição se a esta "der causa" - vale dizer, se, com sua recusa expressa, ou por sua desídia, negligência ou outro comportamento culposo, tiver sido o responsável direto pela não interrupção.

Ilustra-se o exposto com a hipótese do assistente que, preocupado em resguardar os interesses do assistido, contrata os serviços de experiente advogado e confia legitimamente na adequada adoção das medidas destinadas à satisfação do crédito. ${ }^{126}$ Suponha-se, então, que o assistente venha a ser surpreendido ao saber que o profissional jamais promoveu qualquer ato idôneo à interrupção da prescrição ou sequer deduziu tese jurídica plausível com vistas a infirmar uma exceção de prescrição. Tendo o assistente adotado a diligência razoavelmente esperada, contra o mesmo não poderá demandar indenização o assistido - no exemplo formulado, porém, poderá o credor prejudicado dirigir a demanda indenizatória em face do advogado desidioso.

123 Segundo Caio Mário da Silva Pereira, se o assistente de pessoa relativamente incapaz "deixar de exercer em tempo oportuno o direito, e por esta razão dele decaia o respectivo titular, responde civilmente pelo dano causado, tal como para a prescrição estabelece o art. 195 do Código. Quanto à segunda parte, consistente em não alegar a decadência oportunamente, a consequência jurídica é a mesma" (PEREIRA, 2016, p. 579). Ainda a elucidar a distinção do tratamento dispensado ao devedor absoluta ou relativamente incapaz, pertinente a lição de Luiz Carpenter: "os relativamente incapazes, porém, tendo intervenção nos atos da vida civil, não mereciam tão excepcional proteção, pelo que a lei permitiu que contra eles corresse a prescrição, embora a mesma lei viesse em seu socorro, dando-lhes ação regressiva contra seus representantes legais, a fim de destes obterem ressarcimento pelos prejuízos que lhes causem quando, omitindo, por dolo ou negligência, de invocar a prescrição, deixem que esta se consume contra eles representados e a favor do prescribente" (CARPENTER, 1958, p. 218).

124 "Garante o Código a ação indenizatória, e não a restituição in integrum, pela qual assegura-se a recuperação do bem, ou o recebimento do equivalente. Estabelecendo a indenização, o montante compreenderá o bem perdido com as perdas e danos, sendo, pois, mais benéfica que a simples restituição" (RIZZARDO, RIZZARDO FILHO e RIZZARDO, 2015, p. 57). Os autores prosseguem: "Como se percebe, não se assegura a anulação do ato ou da perda do direito à ação. A prescrição consumou-se, e não volta atrás. Cabe unicamente o ressarcimento" (Ibid., p. 58). Trata-se de solução semelhante à adotada pelo CC1916: "A garantia do art. 164 substitui, nesta parte, o benefício da restituição in integrum, e é mais justa do que ele, porque exige a indenização de quem responde pela conservação dos bens, ao passo que a restituição ia destruir uma situação jurídica, que se criara à sombra do direito. O art. 169, I, afasta os incapazes do art. $5^{\circ}$ dos efeitos da prescrição; o art. 164 , atenua-os quanto aos outros incapazes" (BEVILÁQUA, 1976, p. 441).

125 Como já se pontuou em doutrina, "pode acontecer que o menor púbere seja órfão e não se encontre sob tutela, e às demais pessoas enumeradas no art. $4^{\circ}$ não tenha sido dado curador. Em tal conjuntura nenhuma aplicação terá o art. 195, visto que não haverá a quem imputar responsabilidade civil pelos prejuízos decorrentes da prescrição" (THEODORO JÚNIOR, 2003, p. 218). Em sentido semelhante, v. RIZZARDO, RIZZARDO FILHO e RIZZARDO, 2015, p. 58.

126 O exemplo remete à lição de Humberto Theodoro Júnior: "Não me parece que se possa entrever a responsabilidade do assistente quando, por exemplo, tenha tomado as providências a seu alcance, contratando advogado legalmente habilitado para defender os direitos do incapaz, e este tenha sido omisso na arguição da prescrição, ou tenha retardado o aforamento da causa em nome do incapaz, deixando vencer o prazo prescricional contra sua pretensão. Em se tratando de matéria técnica, não está, na maioria dos casos, ao alcance do genitor, tutor ou curador saber como e quando se valer da prescrição ou dela se defender. Haverá, sempre, portanto, que confiar o problema a quem tenha condições de enfrentá-lo com a devida técnica. Na falta de busca desse socorro profissional é que se poderá, na maioria dos casos, localizar a culpa e a consequente responsabilidade do assistente pelas consequências da prescrição desfavoráveis ao incapaz" (THEODORO JÚNIOR, 2003, p. 216).

127 Verbis: "Art. 164. As pessoas que a lei priva de administrar os próprios bens, têm ação regressiva contra os seus representantes legais, quando estes, por dolo, ou negligência, derem causa à prescrição". 
Esse juízo valorativo sobre a conduta do assistente, a despeito da aparentemente clara opção legislativa, é objeto de expressiva divergência doutrinária, cuja origem parece remontar à diversidade de redação entre o art. 195 do Código Civil de 2002 e o correspectivo art. 164 do Código Civil de 1916. ${ }^{127}$ Com efeito, sob a égide da codificação anterior, parecia mais evidente a adoção do regime de responsabilidade civil subjetiva, uma vez que o referido art. 164 fazia menção expressa ao "dolo ou negligência" do assistente causador da prescrição. ${ }^{128}$ Desse modo, somente quando se comprovasse a desídia do assistente em interromper o decurso do prazo prescricional é que restaria deflagrada a sua responsabilidade perante o incapaz assistido. Alheio a esse entendimento, relativamente consolidado em doutrina, o Código Civil de 2002 instaurou ampla controvérsia quando optou por deixar de mencionar o "dolo" ou a "negligência" do assistente. Teria o legislador, com a nova redação, pretendido afastar a sistemática da responsabilidade subjetiva em prol da responsabilidade objetiva?

Argumenta-se, em sentido favorável à aventada mudança de entendimento, que a redação do art. 195 do Código Civil, ao suprimir a referência a critérios de valoração da conduta causadora de dano, haveria de levar à incidência da cláusula geral de responsabilidade objetiva do art. 927, parágrafo único do Código Civil. ${ }^{129}$ Todavia, diante da iniquidade de se estender o referido regime a pessoas que, no mais das vezes, não detêm expertise particularmente destacada para a prática de atos negociais e sequer auferem especial vantagem, parte da doutrina passou a pugnar pela aplicação mitigada da sistemática da responsabilidade independente de culpa. ${ }^{130}$ Começa a ganhar força, gradativamente, a percepção da necessidade de se levar em conta a conduta concreta do assistente que deixa de obstar a consumação da prescrição. ${ }^{131}$

Em meio às dúvidas aventadas pela doutrina, faz-se imprescindível compreender o sistema de responsabilidade civil adotado pelo direito brasileiro, estruturado pelo Código Civil em torno de duas cláusulas gerais. ${ }^{132}$ De uma parte, da combinação entre o art. 186 e o caput do art. 927, depreende-se a cláusula geral de responsabilidade civil subjetiva, a demandar a comprovação do elemento subjetivo da culpa como requisito para a deflagração do dever de indenizar. De outra parte, o parágrafo único do art. 927 consagra a cláusula geral de responsabilidade civil objetiva, cuja deflagração prescinde de qualquer investigação acerca da culpa do agente, bastando a comprovação de dano indenizável e de nexo de causalidade entre o dano e a atividade lesiva. Diante desse cenário normativo, a identificação do regime de responsabilidade civil aplicável não resta relegada ao arbítrio do intérprete. Cumpre-lhe perquirir, em realidade, se estão presentes os requisitos da cláusula geral de responsabilidade independente de culpa, cuja ausência deve necessariamente levar à aplicabilidade do regime subjetivo.

128 “O representante em tais casos responde pela perda ou diminuição do patrimônio, consequência a que fatalmente conduzirá a prescrição, não sendo justo que obrigado ele ficasse também no caso de ausência de dolo ou negligência. Em geral, pelo menos a negligência existe, pois é dever do representante do menor não deixar prescrever o direito do incapaz, ainda que no momento pareça não convir intentar a ação. Suponha-se, por exemplo, que o devedor esteja em má situação financeira e que, no momento, não convém de todo intentar a ação que seria improdutiva. O dever do representante do incapaz é de fazer interromper a prescrição por qualquer dos meios previstos pelo art. 172 [do CC 1916], pois, se mais tarde o devedor vier a refazer a sua situação financeira, o incapaz não será prejudicado. Nesse caso, qualquer prejuízo constatado com a possibilidade de uma boa liquidação posterior somente poderá ocorrer por conta da negligência do representante do incapaz, podendo este intentar a ação regressiva aqui prevista" (SANTOS, 1986, p. 390). A propósito da exigência de comprovação de dolo ou negligência de que tratava o art. 164 do Código Civil de 1916, v. VALLE, 1950, p. 20-21.

129 "Terá pretendido o legislador configurar, agora, no caso, uma responsabilidade objetiva, que só se exclui em caso fortuito ou força maior" (CAHALI, 2008, p. 64)

130 Nesse sentido, parte da doutrina sustenta que "poder-se-ia entender que a responsabilidade dos assistentes ou representantes é alcançada pelo disposto no art. 927, par. ún. [...] A aplicação do dispositivo, que contempla a responsabilidade sem culpa para as hipóteses do art. 195, deve levar em conta as particularidades do caso concreto, não devendo se estender, de modo absoluto, à responsabilidade do art. 927, par. ún., uma vez que, se o representante legal de pessoa jurídica, na maior parte das vezes, possui experiência na atividade que desempenha, podendo assim ser responsabilizado como um profissional, [...] o mesmo não ocorre com o assistente do relativamente incapaz" (BARBOZA, BODIN DE MORAES e TEPEDINO, 2014, p. 369-370).

131 "Com efeito, o assistente do relativamente incapaz poderá, em grande parte das vezes, não possuir conhecimentos jurídicos, nem experiência na vida prática para auxiliar na gestão de interesses de terceiros. O pai ou a mãe de um menor, relativamente incapaz, que deixar de alegar a prescrição benéfica ao assistido não poderá ser submetido à responsabilidade sem culpa, tal qual o representante legal de uma pessoa jurídica, do qual normalmente se requer alguma expertise mínima para a vida negocial” (BARBOZA, BODIN DE MORAES e TEPEDINO, 2014, p. 370).

132 Como registra Maria Celina Bodin de Moraes, "entende-se que a responsabilidade objetiva não veio substituir ou eliminar a responsabilidade fundada na culpa. Considera-se geralmente que nas relações interindividuais, a adoção da responsabilidade subjetiva ainda se apresenta como conveniente, ficando a responsabilidade objetiva reservada especialmente às relações em que há intrínseca desigualdade entre as partes" (BODIN DE MORAES, 2006, p. 19-20). 
No que tange ao art. 195 do Código Civil, a análise do dispositivo não permite verificar qualquer desses requisitos, sendo certo que, a despeito do profícuo debate doutrinário sobre o alcance da expressão, não se pode considerar a assistência a incapaz uma "atividade de risco", tal como preconizada pelo parágrafo único do art. 927 do Código Civil. ${ }^{133}$ Impõe-se a conclusão, portanto, da natureza subjetiva da responsabilidade civil dos assistentes. ${ }^{134}$ Justamente por se tratar de responsabilidade subjetiva, somente recairá dever de indenizar sobre o assistente caso reste demonstrada a sua culpa em sentido normativo, ${ }^{135}$ i.e., o desvio em relação ao padrão de conduta esperado para atividade da mesma natureza no caso concreto. ${ }^{136}$

A norma do art. 195 do Código Civil, portanto, seria, a rigor, despicienda, pois, na ausência de previsão legal específica de incidência do regime de responsabilidade objetiva, presume-se que o regime aplicável será o subjetivo. A ressalva, porém, de que o assistente deve ter "dado causa" à prescrição se revela útil para destacar que, na lógica legislativa, a iniciativa de interrupção da prescrição incumbe, em princípio, ao próprio credor relativamente incapaz, e não ao seu assistente, de modo que ao último não poderia ser imputado qualquer dever de indenizar quando a inércia foi do próprio menor assistido. Não seria demais destacar ainda que o art. 195 do Código Civil não tem o escopo de instaurar uma hipótese de responsabilidade civil independente de prova específica do dano alegado pelo assistido. Portanto, se o devedor do menor relativamente incapaz, por exemplo, renunciando ao benefício da prescrição, paga o débito espontaneamente, não haverá que se falar em prejuízo indenizável, ainda que tenha havido desídia do assistente na interrupção da prescrição.

Como se percebe, as precedentes considerações revelam o acerto do legislador (ou, ao menos, a coerência interna do Código Civil) em restringir a ação indenizatória dos credores relativamente incapazes prejudicados pela prescrição aos casos em que seus assistentes tenham dado causa à extinção da pretensão. Resta investigar, então, se semelhante acerto se verifica também no que tange ao incapaz devedor, precisamente aquele que pode ser prejudicado pela não alegação da prescrição que corria em seu benefício. Aqui coloca-se a questão: por que o art. 195 do Código Civil restringe a ação indenizatória aos relativamente incapazes quando seus representantes (rectius, assistentes) deixarem de alegar a prescrição em seu favor? Não caberia estender essa proteção aos absolutamente incapazes a fortiori, já que eles são mais vulneráveis e normalmente não participam pessoalmente dos atos que lhes dizem respeito?

A redação originária do Código Civil poderia sugerir que tal diferenciação se devia à previsão contida no art. 194, de que o juiz só poderia reconhecer de ofício a prescrição que corresse a favor do absolutamente incapaz. Nessa cognoscibilidade ex officio residiria, supostamente, a razão da restrição da ação indenizatória aludida pelo art. 195 aos relativamente incapazes. Em que pese o aparente acerto, tal

133 Sobre a noção de "atividade de risco", veja-se a lição de Maria Celina Bodin de Moraes: "Atividades que 'por sua natureza' geram riscos para os direitos de outrem são as atividades perigosas. A propósito, a doutrina italiana adota comumente dois critérios para definir as atividades perigosas, previstos pelo art. 2.050 do CCi. [...] A atividade é considerada perigosa, portanto, quando, do ponto de vista estatístico, causa danos quantitativamente numerosos e qualitativamente graves" (BODIN DE MORAES, 2006, p. 28).

134 A favor da qualificação da hipótese como responsabilidade civil subjetiva, Humberto Theodoro Júnior afirma: "Parece que se optou [no CC2002] por uma responsabilidade mais ampla, vinculada simplesmente à falta de exercício da pretensão, correspondente ao crédito do incapaz, ou à não arguição da prescrição que atuaria em favor deste, quando demandado por crédito de terceiro. Não se pode, no entanto, qualificar dita responsabilidade como objetiva, visto que pressupõe uma falha no dever de prestar assistência ao incapaz. Em sua base, portanto, está uma omissão de cautela necessária, configuradora de culpa lato sensu" (THEODORO JÚNIOR, 2003, p. 215).

135 A menção à culpa como elemento subjetivo do ilícito objetiva tão somente destacar a necessidade de valoração da conduta individual do agente, sem que com isso se retorne à antiquada investigação das razões psicológicas subjacentes à conduta. Adota-se, em suma, o paradigma da culpa normativa, pautado na utilização de padrões objetivos de análise da adequação da conduta ao padrão esperado. A propósito, v., com ampla referência bibliográfica, SOUZA, 2015-A, p. 174 e ss.

136 Assim já concluía Pontes de Miranda sobre a codificação anterior: "Se a alguém nasce, contra o relativamente incapaz, ou a mulher casada, exceção de prescrição, oponível em ação pessoal ou real, e houve culpa (= dolo ou negligência) do pai, ou mãe, titular do pátrio poder, ou do tutor, ou do curador, ou do marido, compõe-se o suporte fático do art. 164 do Código Civil [de 1916] [...]. O ato negativo do que administra o interesse lesado, com o nascimento da inevitada exceção de prescrição, entra no mundo jurídico como ato ilícito relativo. Dizemos ato ilícito relativo, porque se trata de violação de dever de diligência, perante o administrado com os pressupostos do art. 164 [do Código Civil de 1916]. Desse ato ilícito relativo irradiam-se dever e obrigação de indenizar, em que, afinal de contas, se resolve, de ordinário, a eficácia da ação regressiva" (MIRANDA, 2013,p. 428-429).Luiz Carpenter exemplifica casos de responsabilidade do assistente: "se o representante legal não teve tempo de interromper a prescrição porque o prazo desta se consumou nas vésperas de ter assumido esse caráter de representantes legal; se não interromper a prescrição porque o sujeito passivo da ação estava em estado de insolvência; não se lhe pode imputar dolo ou negligência, e, portanto, nenhuma ação regressiva tem contra ele o relativamente incapaz" (CARPENTER, 1958, pp. 330-331). 
linha de justificativa não convence, principalmente quando se leva em consideração que a previsão legal de cognoscibilidade ex officio pelo julgador não tem o condão de impedir a ocorrência fática da satisfação do crédito oposto ao incapaz. Nada impede, com efeito, que se satisfaça esse crédito independentemente do reconhecimento da prescrição já consumada em benefício do incapaz devedor, sendo amplamente admitida a possibilidade de renúncia à prescrição pela pessoa a quem ela aproveita.

Diante do atual panorama normativo, todavia, sequer se fazem necessárias tais considerações, uma vez que o referido art. 194 foi revogado pela Lei ${ }^{0} 11.280 / 2006{ }^{137}$ Desde então, admite-se ao julgador a possibilidade de conhecer de ofício a prescrição em favor de qualquer das partes - possibilidade ratificada pelo art. 487, II, do CPC. Tem-se, então, que qualquer devedor - e, no que tange ao objeto precípuo do presente estudo, qualquer devedor incapaz - pode ser prejudicado pela ausência de alegação oportuna da prescrição em sede de defesa ou pelo pagamento de dívida prescrita. Como se percebe, não somente o devedor relativamente incapaz, mas igualmente (e com maioria de razão) o devedor absolutamente incapaz, pode ser prejudicado caso seu representante deixe de arguir oportunamente exceção fundada na prescrição ou pague espontaneamente um débito não mais exigível.

Nesse contexto, retomando-se a análise do art. 195 do Código Civil, constata-se que o dispositivo peca por misturar as situações do incapaz credor e do incapaz devedor. A confusão começa com a escolha legislativa de tratar, no mesmo dispositivo, das hipóteses em que os representantes legais "derem causa à prescrição" (situação que, por imperativo lógico, há de se referir apenas ao incapaz credor, contra quem corre a prescrição) e das hipóteses em que os representantes "não a alegarem oportunamente" (situação que, por idêntica dedução, somente pode dizer respeito ao incapaz devedor, a favor de quem corre a prescrição e que poderia, portanto, alegá-la em defesa). O efetivo problema, porém, reside no fato de a literalidade do art. 195 do Código Civil fazer referência exclusivamente aos relativamente incapazes, evidentemente preocupando-se em resguardar a situação do relativamente incapaz credor, pois contra ele corre prescrição e seu assistente pode "dar causa à prescrição".

De fato, não faria sentido prever ação regressiva do absolutamente incapaz credor contra seu representante, uma vez que contra ele não corre a prescrição (art. 198, I, do Código Civil). O equívoco do legislador foi, então, o de olvidar que o representante do absolutamente incapaz (muito mais que o assistente do relativamente incapaz) pode "deixar de alegar" a prescrição que corre em favor do incapaz devedor. Mesmo diante da possibilidade de reconhecimento da prescrição ex officio pelo juiz, em linha de princípio é possível que o absolutamente incapaz se veja prejudicado pela conduta do representante que deixou de alegar a prescrição - o que pode fazer ainda mais sentido na já mencionada hipótese de pessoa com deficiência mental, em relação à qual pode haver dúvida sobre a ocorrência, ou não, de prescrição. Se o assistente do relativamente incapaz que deixar de alegar a prescrição em seu favor responderá perante o assistido (literalidade do art. 195 do Código Civil), então por que o representante do absolutamente incapaz não deveria responder em semelhante circunstância?

137 "O mencionado dispositivo previa uma única exceção, em favor do absolutamente incapaz, que, desse modo, passara a gozar de maior proteção em face dos efeitos negativos da prescrição. Contudo, esse quadro foi alterado pela Lei $n$. 11.280, de 16 fevereiro de 2006 , que, além de revogar o art. 194 do CC, alterou a redação do $\S 5^{\circ}$ do art. 219 do CPC, passando a admitir a decretação de ofício da prescrição pelo juiz, inclusive nas causas relativas a direitos patrimoniais. Aparentemente, o legislador veio atender ao pleito da Fazenda Pública, antes não contemplada com a possibilidade de o juiz conhecer da prescrição de ofício, mecanismo que, como visto, apenas beneficiava o absolutamente incapaz" (BARBOZA, BODIN DE MORAES e TEPEDINO, 2014, p. 356)

${ }^{138}$ Ferreira Coelho esclarece a confusão conceitual inaugurada pelo art. 164 do CC 1916 no que tange à menção de "representantes legais" de pessoas relativamente incapazes: "O art. 164 fala em representantes; combinando-se a disposição deste artigo com a do art. 426 , pode-se supor uma antinomia ou incongruência, pois o art. 164 refere-se à representação, e o art. 426 diz que o tutor representa os menores de 16 anos; estes não estão sujeitos à prescrição; os maiores de 16 e menores de 21 anos são assistidos pelo tutor nos atos em que forem parte. Mas o mesmo art. 426 do volve à dúvida, dizendo: suprindo-lhe o consentimento; de onde se vê que assistir equivale a representar, para o efeito do art. 164" (COELHO, 1933, p. 356). O autor prossegue: "Efetivamente, o tutor, assistindo o menor de 21 e maior de 16 anos em um ato em que este é parte, dá o seu consentimento para a prática do ato, e nestas condições fica responsável pelo seu mau efeito, se praticar com dolo ou negligência. Neste caso a responsabilidade do tutor é a mesma que se praticasse o ato sem a presença do menor; pela sua assistência ou consentimento aprovou o ato que não teria efeito, se não fosse por ele assistido; dando plácito à intenção do menor, representou-o, suprindo a capacidade que Ihe faltava para o ato" (Ibid., p. 356). Na mesma linha de sentido, a apontar a confusão conceitual em que incorreu o Código Civil de 1916 ao falar em "representantes legais" quando se referia aos assistentes de relativamente incapazes, v. FISCHER, 1957, p. 425. 
Some-se a tais considerações a constatação de que o art. 164 do CC 1916, inspirador do atual art. 195, apenas se referia à hipótese em que os "representantes legais" (sic) "dessem causa" à prescrição i.e., deixassem de exercer a pretensão titularizada pelo incapaz credor. ${ }^{138}$ Como também na vigência do Código anterior não corria prescrição contra os absolutamente incapazes (art. 169, I, do CC1916), veio a prevalecer a interpretação doutrinária de que o art. 164 do CC 1916, ao se referir às "pessoas que a lei priva de administrar os próprios bens", referia-se apenas aos relativamente incapazes. ${ }^{139}$

A consolidação de tal entendimento a propósito do art. 164 do CC 1916 parece ter levado o legislador de 2002 - e, em sua companhia, parte expressiva da doutrina - a fechar aos olhos à imperiosa distinção de tratamento sobre as situações do incapaz credor (contra quem a prescrição corre) e do incapaz devedor (a favor de quem a prescrição corre). ${ }^{140}$ Por todas as razões, parece adequado concluir que o art. 195 do Código Civil merece, por um lado, interpretação extensiva quanto aos absolutamente incapazes, para permitir que tenham ação indenizatória contra os representantes que não alegarem a prescrição oportunamente; e, por outro lado, interpretação restritiva quanto aos relativamente incapazes, para apenas condicionar a responsabilidade do assistente à comprovação de culpa em sentido normativo.

\section{Conclusão}

Precipuamente concebida para fins de identificação da (in)validade dos atos praticados por certas pessoas, matéria em que o discernimento do agente desempenha um papel crucial, a incapacidade civil por vezes é utilizada pelo legislador como um indicador do grupo de pessoas que se sujeitam à disciplina de outros institutos, como ocorre no caso das causas suspensivas e impeditivas da prescrição. Isso provavelmente se dá porque, também em matéria de prescrição e decadência, entende o legislador que o nível de discernimento apresentado pelo titular do direito será relevante para determinar sua autorresponsabilidade pelas consequências negativas advindas da inércia em seu exercício. Essa perspectiva se coaduna com a aplicação, em sede doutrinária, de teorias como a actio nata e o brocardo contra non valentem agere non currit praescriptio, em acepções paulatinamente forjadas pela doutrina para indicar, como já fazem expressamente diversos ordenamentos estrangeiros, que certas impossibilidades de fato ou de direito devem ser levadas em conta para indicar o termo inicial da prescrição.

Nesse sentido, torna-se possível propor, em perspectiva funcional, uma releitura das causas suspensivas e interruptivas da prescrição, mais atenta à realidade concreta do titular do direito e sua eventual vulnerabilidade. Tal abordagem oferece novas respostas a antigos problemas, como o do relativamente incapaz que se encontre eventualmente desprovido de assistente (e que sofre, em tese, os efeitos regulares da prescrição). É possível sustentar que o curso da prescrição em seu desfavor está obstado, já que não lhe é dado praticar validamente atos de interrupção até que seja nomeado novo assistente ou cesse a incapacidade. De outra parte, surgem saídas para novos problemas, como o das pessoas com deficiência intelectual e psíquica que se tornaram plenamente capazes no regime instituído pela Lei Brasileira de Inclusão. Para elas, é ainda possível aplicar analogicamente o óbice à prescrição previsto pelo art. 198, I, do Código Civil, a partir do momento em que seu nível de discernimento seja comprovadamente reduzido ao ponto de impossibilitar o regular exercício dos atos de interrupção da

\footnotetext{
139 “As pessoas absolutamente incapazes não são compreendidas pelo art. 164, pela simples razão de que contra elas não corre prescrição, como preceitua expressamente o art. 169. Portanto, temos de nos ocupar das pessoas naturais, relativamente incapazes, e das pessoas legais, ou jurídicas, como chama o Código" (COELHO, 1933, p. 355). No mesmo sentido, v. CARPENTER, 1958, pp. 214-216; FRANCO, 1954, pp. 52-54; VALLE, 1950, p. 65; e FISCHER, 1957, p. 425; SANTOS, 1986, pp. 389-390; e BEVILÁQUA, 1976, p. 441. Em sentido diverso, a sustentar que o art. 164 do CC1916 se referia aos absolutamente incapazes, v. BARBOZA, BODIN DE MORAES e TEPEDINO, 2014, p. 369.

140 Veja-se, ilustrativamente, a lição de Humberto Theodoro Júnior, que não leva em consideração um dos aspectos do dispositivo em comento (incapaz devedor cujo representante deixa de invocar prescrição em sua defesa): "Não se refere a regra do citado art. 195 aos absolutamente incapazes; primeiro, porque o texto legal é claro, ao prever a responsabilidade do assistente apenas em favor do relativamente incapaz; segundo, porque não haveria como, tecnicamente, ocorrer a hipótese de um absolutamente incapaz ser prejudicado pela prescrição. Quando o Projeto do novo Código tramitava no Congresso, houve emenda que sugeria a introdução dos absolutamente incapazes entre os contemplados no dispositivo que veio a converter-se no atual art. 195. A proposição foi desacolhida pela Comissão Revisora [...]" (THEODORO JÚNIOR, p. 216217).
} 
prescrição. Finalmente, também o remédio indenizatório previsto pelo art. 195 do Código Civil deve ser revisitado sob a mesma ótica, sendo certo que a pretensão reparatória deve atender igualmente aos incapazes que, na posição de devedores, poderiam ter sido beneficiados pela prescrição e não o foram pela desídia de seus assistentes (o que há de abranger, evidentemente, os absolutamente incapazes, a despeito da redação legal).

Os problemas decorrentes da compatibilização do regime da prescrição e decadência com o sistema da incapacidade civil, particularmente em sua configuração atual no direito brasileiro, demonstram, como se afirmou anteriormente, a perene necessidade de se revisitar a teoria geral do direito civil. Em perspectiva civil-constitucional, impõe-se mitigar o rigor estruturalista dos referidos institutos em busca de uma lógica funcional e valorativa, que sugere a revitalização do critério do discernimento em matéria de incapacidade civil e uma maior valorização do termo inicial de fluência como parâmetro decisivo para a proteção dos interesses das partes sujeitas à prescrição e decadência, matérias aqui identificadas como problemas de merecimento de tutela em sentido estrito. Não devem prosperar, nesse sentido, os entendimentos que findem, direta ou indiretamente, por fazer da prescrição e da decadência institutos infensos à tábua axiológica constitucional.

\section{Referências}

ALVES, José Carlos Moreira. A Parte Geral do Projeto de Código Civil brasileiro. São Paulo: Saraiva, 1986.

AMARAL, Francisco. Direito civil: introdução. 8. ed. Rio de Janeiro: Renovar, 2014.

AUBRY, Charles; RAU, Charles. Cours de droit civil français d'après la méthode de Zachariae. 5. ed. Paris: ILGJ, 1897. t. II.

BARBOZA, Heloisa Helena; BODIN DE MORAES, Maria Celina; TEPEDINO, Gustavo (Org.). Código Civil interpretado conforme a Constituição da República. 3. ed. Rio de Janeiro: Renovar, 2014. v. I.

BEVILÁQUA, Clóvis. Código Civil dos Estados Unidos do Brasil comentado. Rio de Janeiro: Rio, 1976. v. I.

BEVILÁQUA, Clóvis. Teoria geral do direito civil. Rio de Janeiro: Rio, 1980.

BIANCA, Massimo. Diritto civile. Milano: Giuffrè, 2012. v. VII.

BOBBIO, Norberto. A função promocional do direito. Da estrutura à função: novos estudos de teoria do direito. São Paulo: Manole, 2007.

BODIN DE MORAES, Maria Celina. Risco, solidariedade e responsabilidade objetiva. Revista dos Tribunais, São Paulo, v. 854, p. 11-37, dez. 2006.

BODIN DE MORAES, Maria Celina. Uma aplicação do princípio da liberdade. Na medida da pessoa humana: estudos de direito civil-constitucional. Rio de Janeiro: Renovar, 2010.

CAHALI, Yussef Said. Prescrição e decadência. São Paulo: RT, 2008.

CARBONNIER, Jean. Droit civil. Paris: PUF, 2004. v. II.

CARPENTER, Luiz Frederico. Da prescrição. 3. ed. Atual. Arnold Wald. Rio de Janeiro: Editora Nacional de Direito, 1958. v. I.

CHAMOUN, Ebert. Instituições de direito romano. Rio de Janeiro: Forense, 1968.

CIANCI, Mirna. Da prescrição contra o incapaz de que trata o artigo $3^{\circ}$, I do Código Civil. In: CIANCI, Mirna (Coord.). Prescrição no Código Civil. São Paulo: Saraiva, 2006.

COELHO, Antônio Ferreira. Código Civil dos Estados Unidos do Brasil comparado, commentado e analysado. Rio de Janeiro: Off. Graphicas, 1933. v. XI.

CORDEIRO, António Menezes. Tratado de direito civil. Coimbra: Almedina, 2015. v. V. 
COSTA, Mário Júlio de Almeida. Direito das obrigações. Coimbra: Almedina, 2016.

DANTAS, Francisco Clementino de San Tiago. Programa de direito civil. Atual. Gustavo Tepedino et al. 3. ed. Rio de Janeiro: Forense, 2001. v. I.

FISCHER, Brenno. A prescrição nos tribunais. Rio de Janeiro: José Konfino, 1957. v. I. t. II.

FRANCO, Ary Azevedo. A prescrição extintiva no Código Civil brasileiro. 2. ed. Rio de Janeiro: Freitas Bastos, 1954.

GAZZONI, Francesco. Manuale di diritto privato. 17. ed. Napoli: ESI, 2015.

GOMES, Orlando. Introdução ao direito civil. Rio de Janeiro: Forense, 2008.

GUEDES, Gisela Sampaio da Cruz; LGOW, Carla Wainer Chalréo. Prescrição extintiva: questões controversas. Revista do Instituto do Direito Brasileiro, Lisboa, ano 3, n. 3, p. 1833-1858, 2014.

LEAL, Antônio Luís da Câmara. Da prescrição e da decadência. Rio de Janeiro: Forense, 1959.

LEITÃO, Luís Manuel Teles de Menezes. Direito das obrigações. Coimbra: Almedina, 2010. v. II.

LEONARDO, Rodrigo Xavier. A prescrição no Código Civil brasileiro (ou o jogo dos sete erros). Revista da Faculdade de Direito da UFPR, Curitiba, n. 51, p. 101-120, 2010.

LÔBO, Paulo. Direito civil: Parte Geral. São Paulo: Saraiva, 2009.

LONGOBUCCO, Francesco. La prescrizione come "rimedio civile": profili di ragionevolezza dell'istituto. I contratti. n. 11, 2012.

LOPES, Miguel Maria de Serpa. Curso de direito civil. Rio de Janeiro: Freitas Bastos, 1996. v. I.

MADALENO, Rolf. Curso de direito de família. 6. ed. Rio de Janeiro: GEN, 2015.

MALAURIE, Philippe; AYNĖS, Laurent. Droit des obligations. 7. ed. Paris: LGDJ, 2016.

MALAURIE, Philippe; AYNĖS, Laurent. Droit des personnes: la protection des mineurs et des majeurs. 8. ed. Paris: LGDJ, 2016.

MEIRELES, Rose Melo Vencelau. A necessária distinção entre negócios jurídicos patrimoniais e existenciais. In: MORAES, Carlos Eduardo Guerra de; RIBEIRO, Ricardo Lodi (Coord.). Direito Civil. Coleção Direito UERJ 80 Anos. Rio de Janeiro: Freitas Bastos, 2015. v. II.

MENEZES, Joyceane Bezerra de. O direito protetivo no Brasil após a Convenção sobre a Proteção da Pessoa com Deficiência: impactos do novo CPC e do Estatuto da Pessoa com Deficiência. Civilistica. com, Rio de Janeiro, ano 4, n. 1, 2015.

MONATERI, Pier Giuseppe. La prescrizione. In: SACCO, Rodolfo (diretto da). Trattato di diritto civile. La Parte Generale del Diritto Civile. Torino: UTET, 2009. v. V.

MOREIRA, José Carlos Barbosa. Notas sobre pretensão e prescrição no sistema do Novo Código Civil brasileiro. Revista da Academia Brasileira de Letras Jurídicas, Rio de Janeiro: ABLJ, v. 19, n. 22, jul.dez. 2002.

OLIVEIRA, Rogério Alvarez de. O novo sistema de (in)capacidades e a atuação do MP na curatela. Revista Consultor Jurídico (Conjur),18. abr. 2016.

PEREIRA, Caio Mário da Silva. Instituições de direito civil. 29. ed. Atual. Maria Celina Bodin de Moraes. Rio de Janeiro: GEN, 2016. v. I.

PEREIRA, Caio Mário da Silva. Instituições de direito civil. 25. ed. Atual. Tânia da Silva Pereira. Rio de Janeiro: GEN, 2017. v. V.

PERLINGIERI, Pietro. Manuale di diritto civile. 7. ed. Napoli: ESI, 2014.

PERLINGIERI, Pietro. O direito civil na legalidade constitucional. Rio de Janeiro: Renovar, 2008.

POTHIER, Robert Joseph. Tratado das obrigações. Campinas: Servanda, 2002.

PUGLIATTI, Salvatore. Autoresponsabilità. Scritti giuridici. Milano: Giuffrè, 2011. v. IV. 
PUGLIATTI, Salvatore. I fatti giuridici. Milano: Giuffrè, 1996.

PUGLIESE, Giuseppe. La prescrizione nel diritto civile. Parte Seconda: la precrizione estintiva. 4. ed. Torino: UTET, 1924.

REQUIÃO, Maurício. As mudanças na capacidade e a inclusão da tomada de decisão apoiada a partir do Estatuto da Pessoa com Deficiência. Revista de Direito Civil Contemporâneo, São Paulo: Revista dos Tribunais, jan.-mar. 2016.

REIS JÚNIOR, Antonio dos. O Estatuto da Pessoa com Deficiência: questões de direito intertemporal. In: MENEZES, Joyceane Bezerra de (Org.). Direito das pessoas com deficiência psíquica e intelectual nas relações privadas. Rio de Janeiro: Processo, 2016.

RIZZARDO, Arnaldo. Parte Geral do Código Civil. 7. ed. Rio de Janeiro: GEN, 2011.

RIZZARDO, Arnaldo; RIZZARDO FILHO, Arnaldo; RIZZARDO, Carine Ardissone. Prescrição e decadência. Rio de Janeiro: Forense, 2015.

RODRIGUES, Silvio. Direito civil. 34. ed. São Paulo: Saraiva, 2007. v. I.

ROSELLI, Frederico. In: LIPARI, Nicolò; RESCIGNO, Pietro. Diritto civile: Attuazione e tutela dei diritti. Tomo II: Attuazione dei diritti. Milano: Giuffrè, 2009. v. IV

SANTOS, João Manoel de Carvalho. Código Civil brasileiro interpretado. 4. ed.Rio de Janeiro: Freitas Bastos, 1950. v. III e VI.

SAVIGNY, Friedrich Karl von. Traité de droit romain. Paris: Firmin Didot Frères, 1858. t. 5.

SILVA, Oscar Joseph de Plácido e. Vocabulário jurídico. Atual. Nagib Slaibi e Priscila Pereira Vasques Gomes. Rio de Janeiro: GEN, 2008.

SILVA, Rodrigo da Guia. Em busca do conceito contemporâneo de (in)adimplemento contratual: análise funcional à luz da boa-fé objetiva. Revista da Advocacia Geral da União, Brasília, v. 16, abr.-jun. 2017.

SOUZA, Eduardo Nunes. Do erro à culpa na responsabilidade civil do médico: estudo na perspectiva civil-constitucional. Rio de Janeiro: Renovar, 2015-A.

SOUZA, Eduardo Nunes. Merecimento de tutela: a nova fronteira da legalidade no direito civil. Revista de Direito Privado, São Paulo: Revista dos Tribunais, v. 58, abr.-jun. 2014.

SOUZA, Eduardo Nunes. Situações jurídicas subjetivas: aspectos controversos. Civilistica.com, a. 4, n. 1, 2015-B.

SOUZA, Eduardo Nunes. Teoria geral das invalidades do negócio jurídico: nulidade e anulabilidade no direito civil contemporâneo. São Paulo: Almedina, 2017.

SOUZA, Eduardo Nunes de; SILVA, Rodrigo da Guia. Autonomia, discernimento e vulnerabilidade: estudo sobre as invalidades negociais à luz do novo sistema das incapacidades. Civilistica.com, Rio de Janeiro, ano 5, n. 1, 2016.

SIMÃO, José Fernando. Prescrição e decadência: início dos prazos. São Paulo: Atlas, 2013.

TEPEDINO, Gustavo. A aplicabilidade do Código Civil nas relações de consumo: diálogos entre o Código Civil e o Código de Defesa do Consumidor. In: LOTUFO, Renan; MARTINS, Fernando Rodrigues (Coord.). 20 anos do Código de Defesa do Consumidor: conquistas, desafios e perspectivas. São Paulo: Saraiva, 2011.

TEPEDINO, Gustavo. Itinerário para um imprescindível debate metodológico. Editorial à Revista Trimestral de Direito Civil, Rio de Janeiro: Padma, jul.-set. 2008. v. 35.

TERRÉ, François; SIMLER, Philippe; LEQUETTE, Yves. Droit civil: les obligations. 11. ed. Paris: Dalloz, 2013.

TESCARO, Mauro. Decorrenza della prescrizione e autoresponsabilità: la rilevanza civilistica del principio contra non valentem agere non currit praescriptio. Padova: CEDAM, 2006. 
THEODORO JÚNIOR, Humberto. In: TEIXEIRA, Sálvio de Figueiredo (Coord.). Comentários ao novo Código Civil. Rio de Janeiro: Forense, 2003. v. III. t. II.

TRABUCCHI, Alberto. Istituzioni di diritto civile. 47. ed. Padova: CEDAM, 2015.

VALLE, Numa Pereira do. Da prescripção extintiva: no direito civil e comercial. São Paulo: Escolas Profissionaes do Lyceu Salesiano Sagrado Coração de Jesus, 1918.

VALLE, Oswaldo de Souza. Da prescrição. Rio de Janeiro: [s.n.], 1950.

VASCONCELOS, Pedro Pais de. Teoria geral do direito civil. 4. ed. Coimbra: Almedina, 2007.

VENANDET, Guy et al. Code civil. 115. ed. Paris: Dalloz, 2016.

WINDSCHEID, Bernhard. Lehrbuch des Pandektenrechts. Ester Band. Düsseldorf: Julius Buddeus, 1862.

ZIMMERMANN, Reinhard. Comparative Foundations of a European Law of Set-Off and

Prescription. Cambridge: Cambridge University Press, 2004.

Autores Convidados 